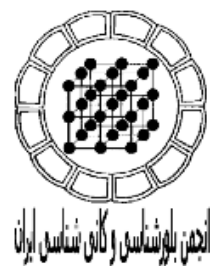

\title{
مقاله يخووهشى
}

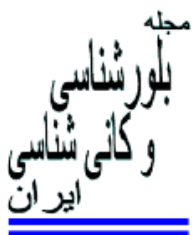

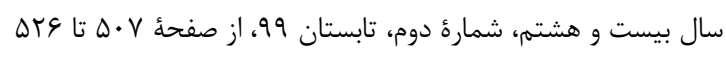

\section{سنَنَگارى و زمينشيمى سنَ ميزبان كربناتى معادن سرب و روى كاروانگًاه و دهنو در شمال كوهبنان،كر مان}

\author{
فاطمه زمانى '، سيدرضا موسوى حرمى "، حامد زندمقدمّ اسداله محبوبى'

$$
\begin{aligned}
& 1 \text { - كروه زمين شناسى، دانشكده علوم، دانشعاه فردوسى مشههد، مشهل، /يران }
\end{aligned}
$$

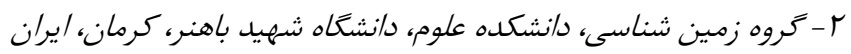

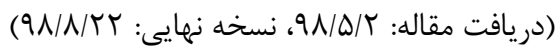

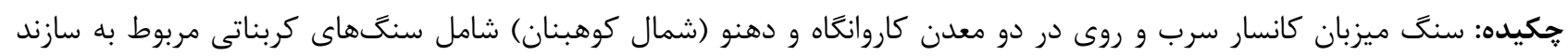

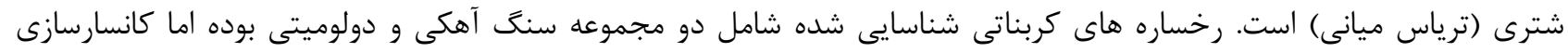

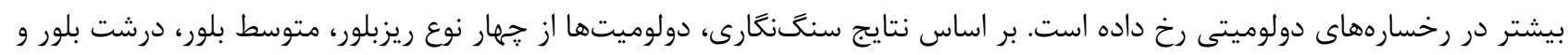

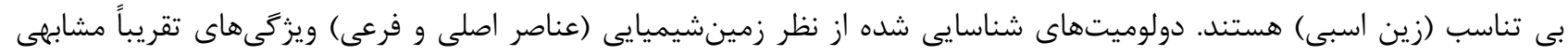

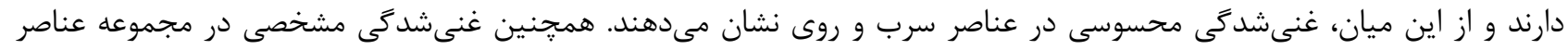

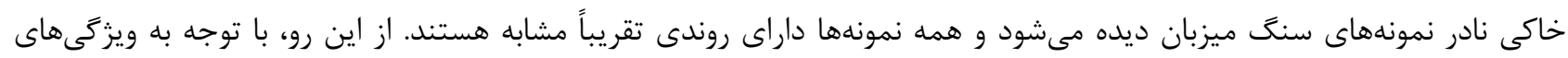

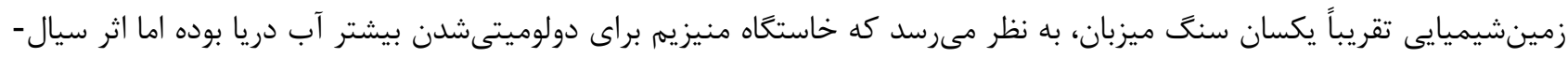
هاى كانهساز در تشكيل دولوميتهاى درشت بلور نيز قابل اهميت است.

$$
\text { وازههاى كليدى: سنكنتارى؛ زمينشيمى؛ دولوميت؛ سرب و روى؛ شمال كوهبنان. }
$$

شيميايى بررسى شده، اما در مورد نهشتهاى سنگ ميزبان مقدمه بررسى جامعى انجام نشده است. از آنجا كه سنى مرانى ميزبان

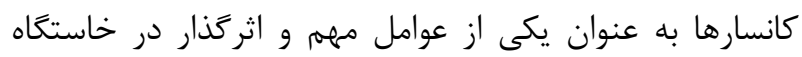

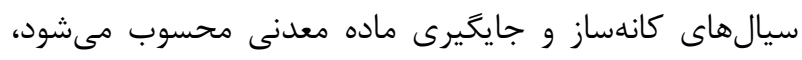

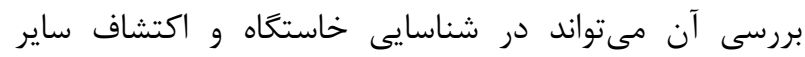

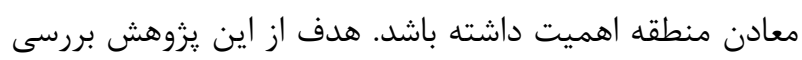

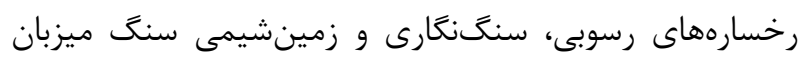

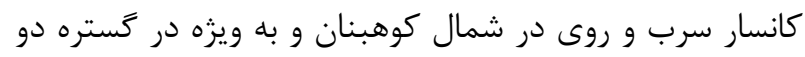

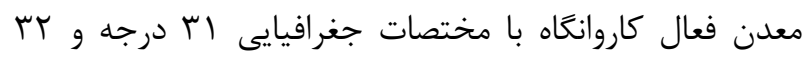

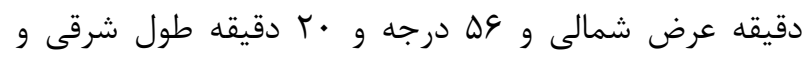

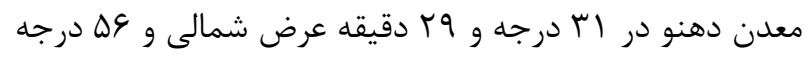

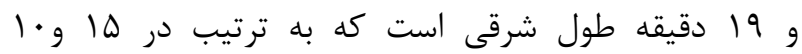
״يرامون شهرستان كوهبنان واقع در شمال استان كرمان،

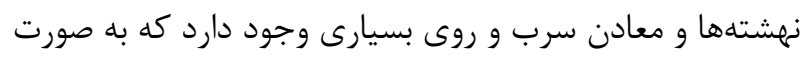

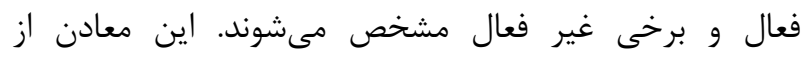

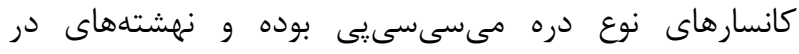

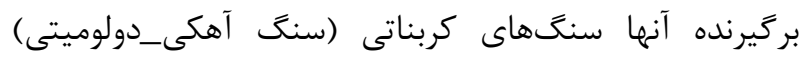

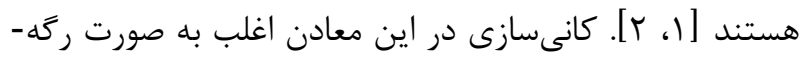

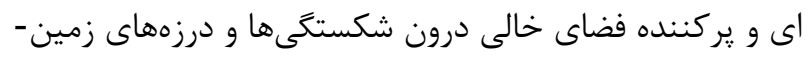

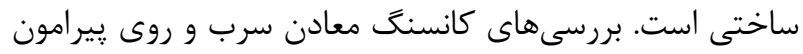
كوهبنان [ـ-ه] نشان داده است كه كالن، سروزيت، اسفالريت،

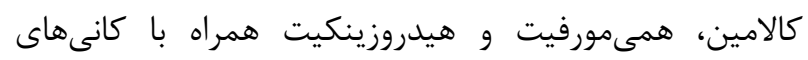
كيلومترى شمال شرق شهرستان كوهبنان قرار دارند (شكل () ).

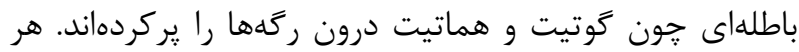
جند كه ماده معدنى از جنبههاى مختلف كانىشناسى و و زمين

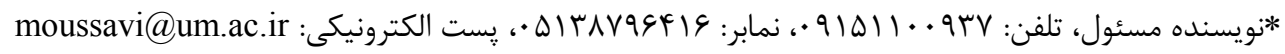




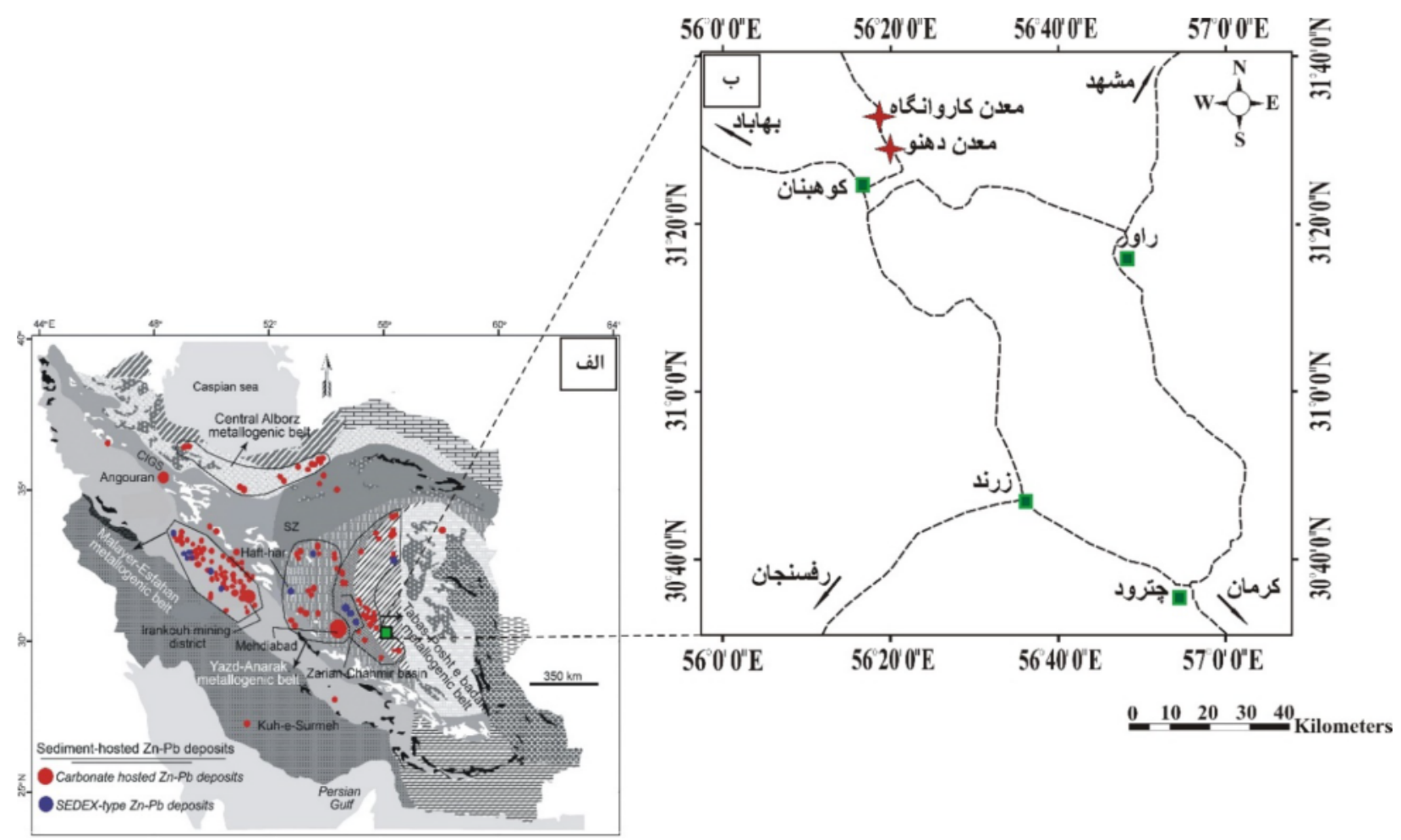

شكل ا الف) جايگاه دو معدن دهنو و كاروانتاه در نقشه كمربندهاى فلززايى سرب و روى ايران (بركرفته از مرجع [1 ا]) و ب) موقعيت جغرافيايى

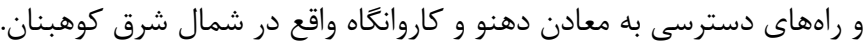

يشت بادام) بين دو گسل اصلى كوهبنان و بهاباد واقع شدهاند.

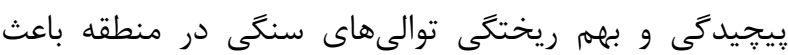

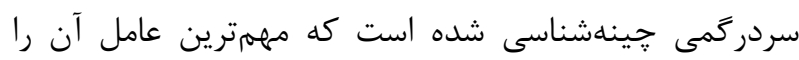

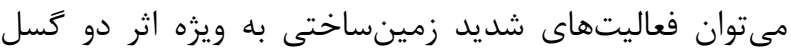

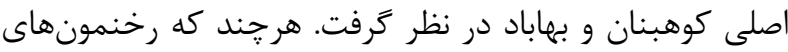

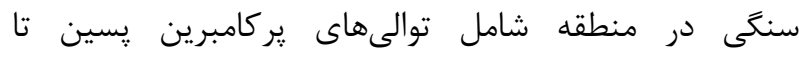

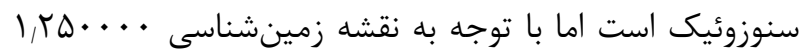

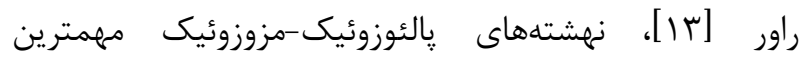
واحدهاى رسوبى منطقه محسوب مىشوند. در شمال كوهبنان،

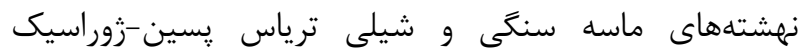
(سازندهاى نايبند و آب حاجى از خروه شمشك) بيشترين ترين رخنمون را دارند و با توجه به نبود فسيلهاى شاخص، مى إتوان از آنها به عنوان نهشتههاى كليدى براى شناسايى ساير سازندها

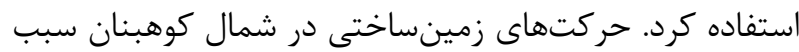
تشكيل جينخوردگىها، ناوديس و تاقديسهايى در مقياس دراس

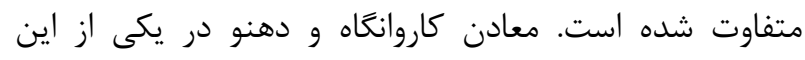
تاقديسها قرار داشته به طورى كه معدن كاروانگاه در يال شمالى (شرقى) و معدن دهنو در يال جنوبى (غربى) قرار دارند.

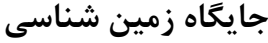

فلززايى در ايران بيشتر نتيجه تكامل زميناسينساختى اقيانوسهاى

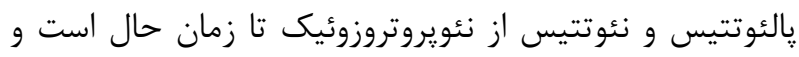

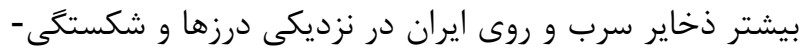

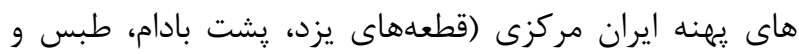

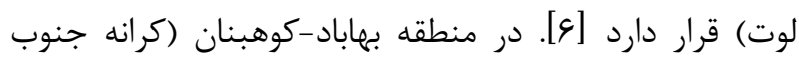

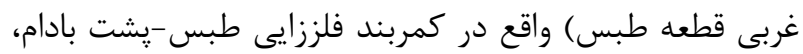

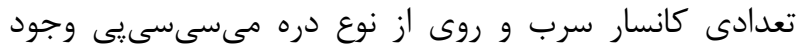

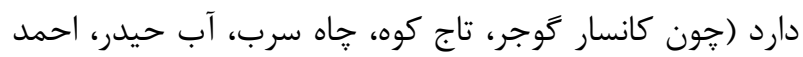

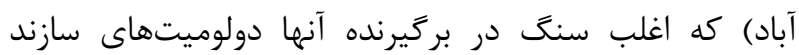

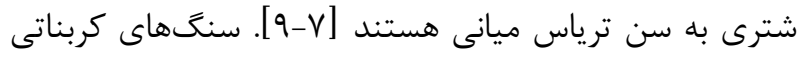

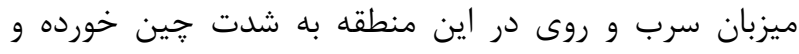

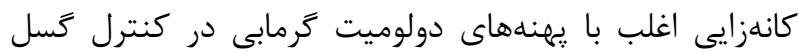

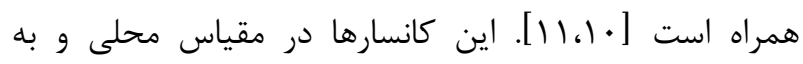
صورت جينه كران در برشها، شكستكىها و فضاهاى خالى قرار

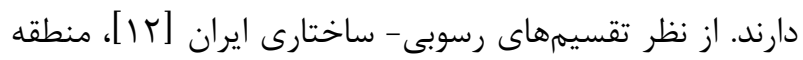

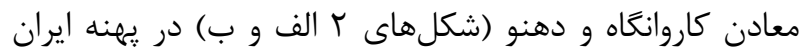
مركزى و بخش غربى قطعه طبس (كمربند فلززايى طبس- دارئ 
نمونه برداشت شدند. از آنجا كه منطقه دستخوش فعاليتهاى زمينساختى مختلفى شده است، اغلب برشهاى جينهشناسى منى

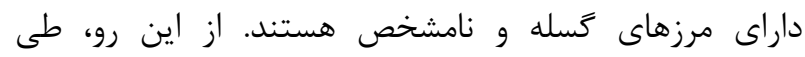
بازديدهاى صحرايى يك برش جينهشناسى كامل از سازند

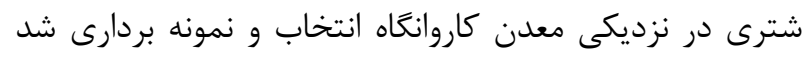

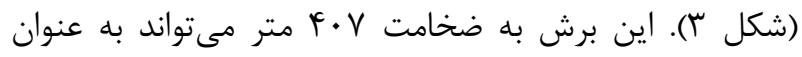
برشى مرجع براى مقايسه سنَ ميزبان سرب و روى در ساير

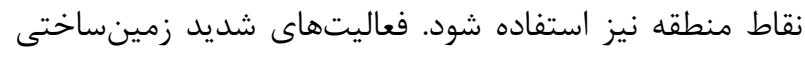
در نزديكى معدن دهنو سبب تكرار و يا حذف برخى از رخسارهها شده است با اين وجود، نمونهبردارى از سنى ميزبان معدن دهنو نيز به صورت تصادفى و با تغيير مشخصات

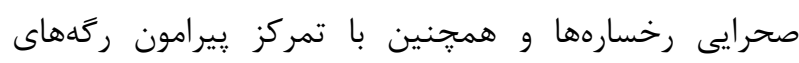

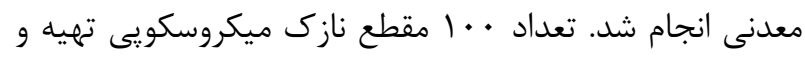

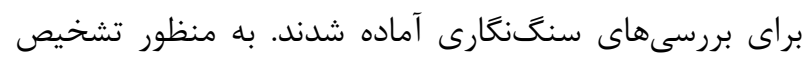

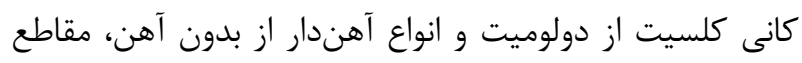

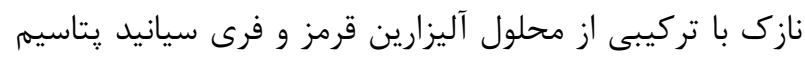

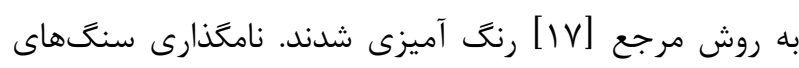
آهكى بر اساس مرجع [11] انجام شد و براى تقسيمهبندى

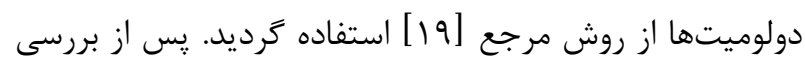

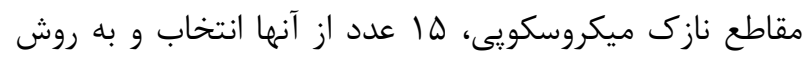

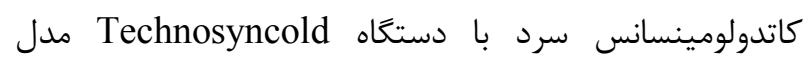

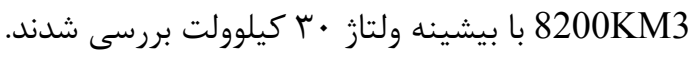

كانسارسازى اغلب در سنَّهاى دولوميتى و گَاهى سنَ آهك دولوميتى رخ داده است كه با مرزى تدريجى اما مشخص (افقى

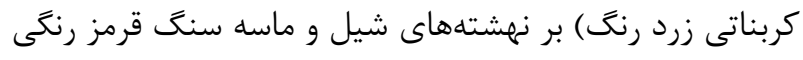

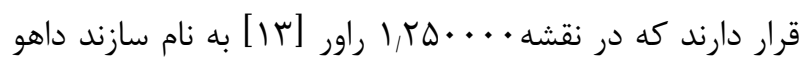
(كامبرين ي קيشين) هستند. نهشتههاى كربناتى سنگ ميزبان در

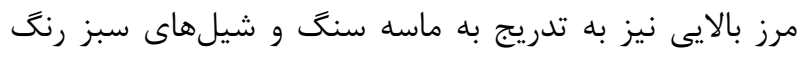

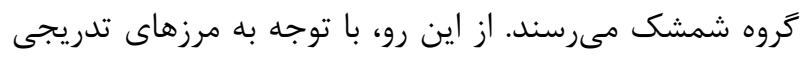

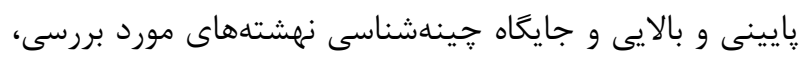
به نظر مىرسد كه نهشتههاى سنگ ميزبان مربوط به سازند

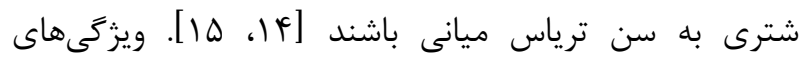

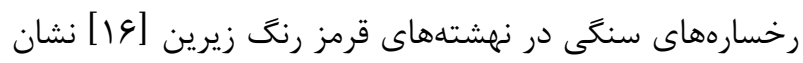
مىدهد كه اين نهشتهها نيز وابسته به سازند سرخ شيل (ترياس ييشين) هستند كه با مرزى تدريجى به نهشته لهاى

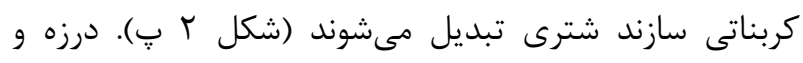

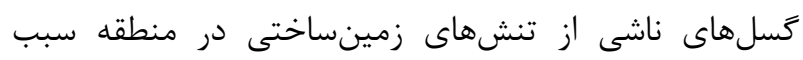
ايجاد فضاهاى خالى مختلفى در سنگهاى كربناتى سازند شترى شده و اين فضا بعدها توسط سيال كانه ساز ير گرديده و ورجئ سرانجام ماده معدنى سرب و روى به صورت متقاطع با لايه بندى (به ندرت موازى با لايهها) تشكيل شده است.

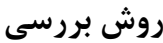

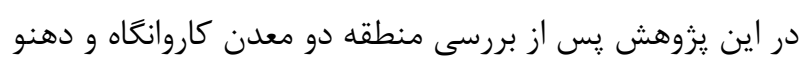

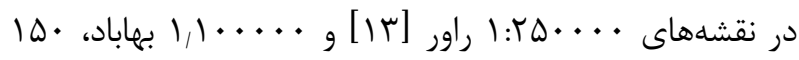
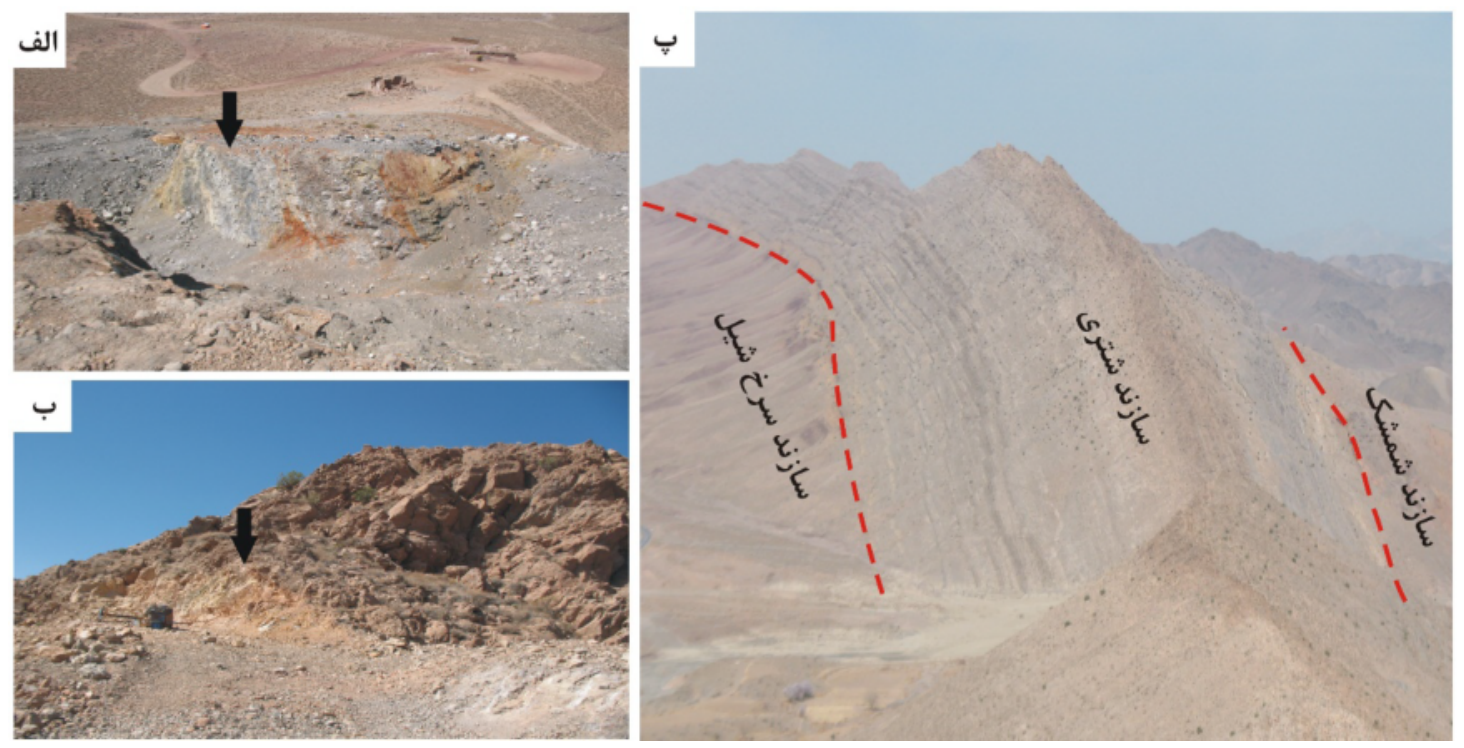

شكل r تصاوير صحرايى از برش اندازهَيرى شده و گستره معدن كارى در منطقه مورد بررسى: الف) نمايى از فعاليتهاى معدنى رو باز در معسدن

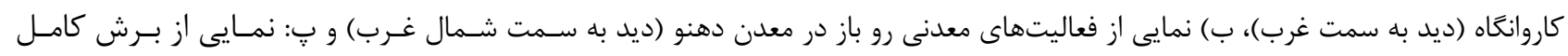

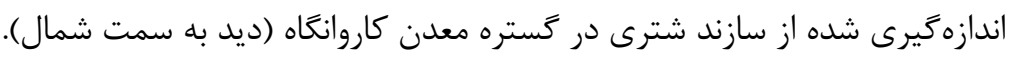




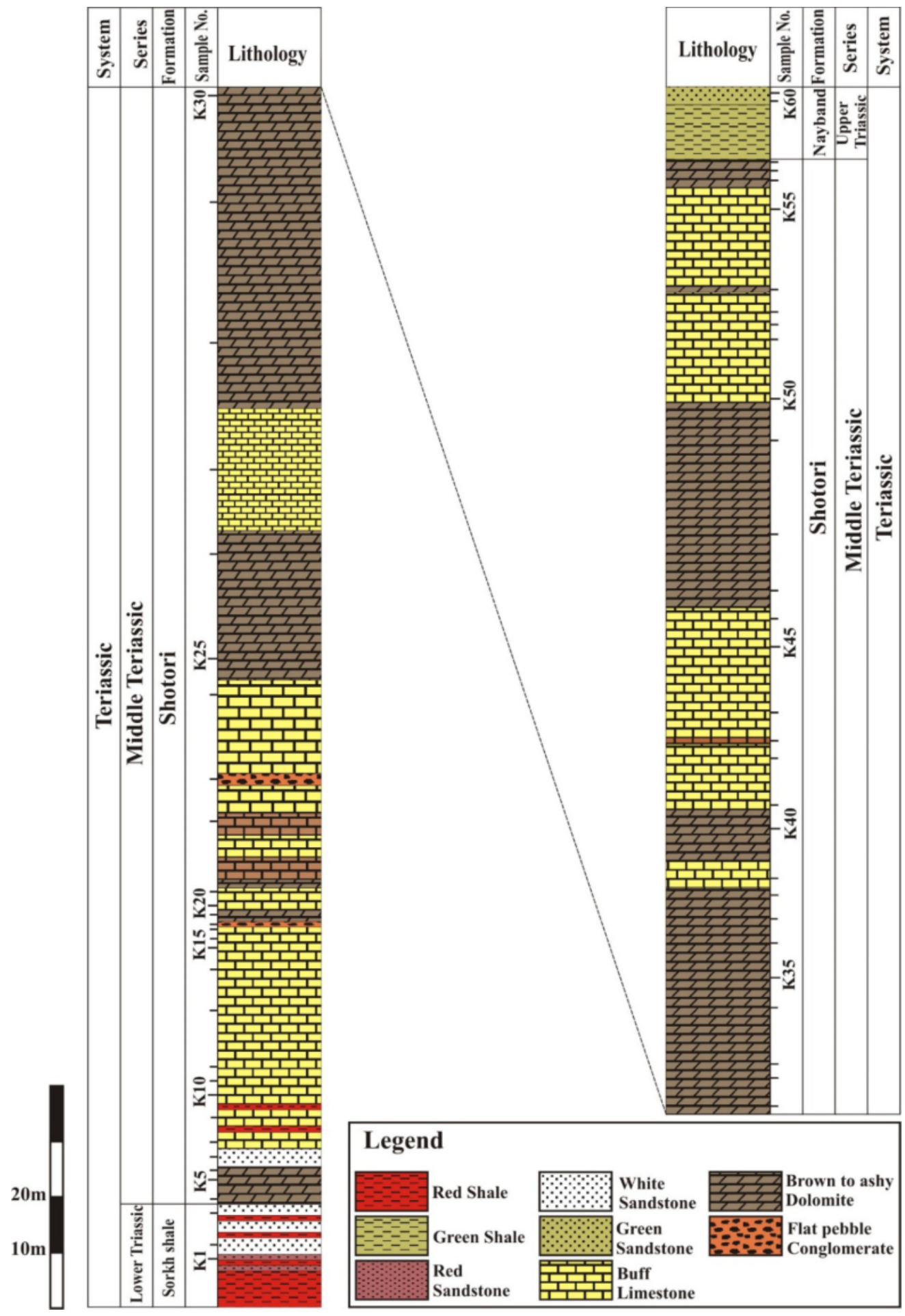

شكل r ستون קينهشناسى سازند شترى در برش مورد بررسى (برش كاروانگاه).

سنگ ميزبان آهكى و دولوميتى به منظور تجزيه عناصر اصلى،

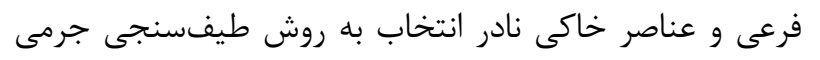

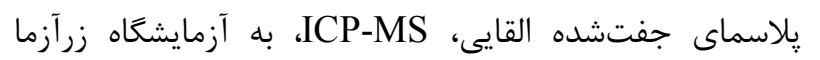

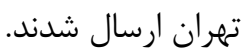

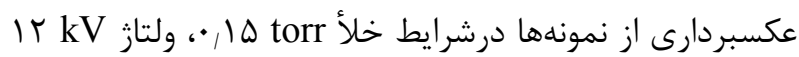

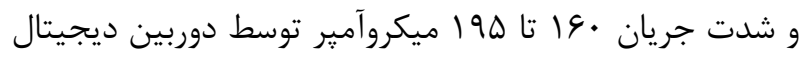

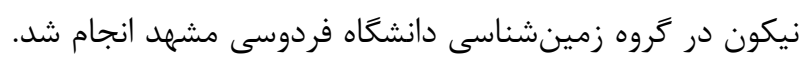

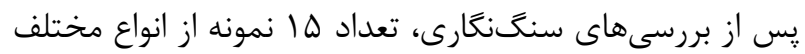


سنَّسبز زيستآوارى: مهمترين دانههاى اسكلتى در اين

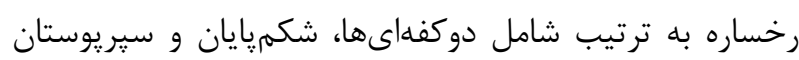

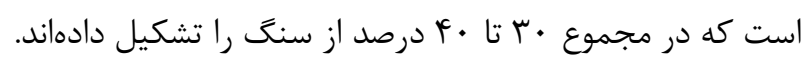

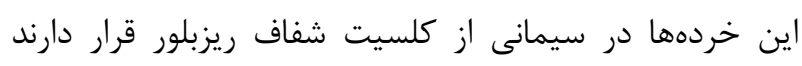

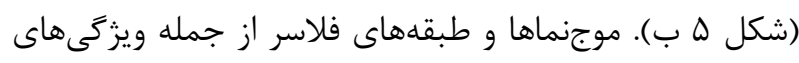

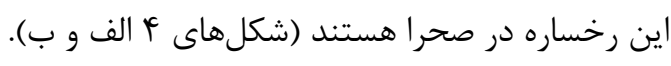

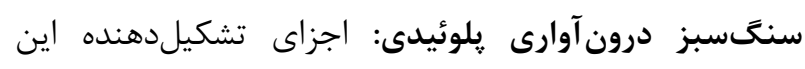

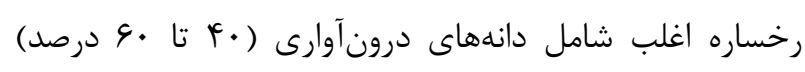

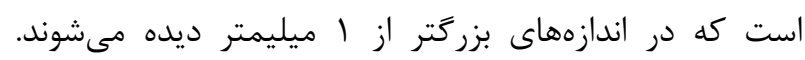

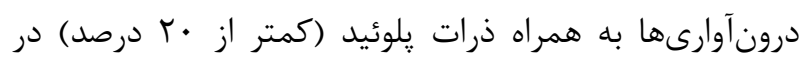

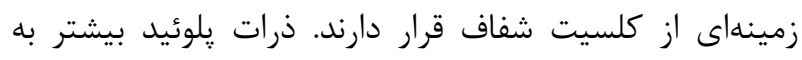

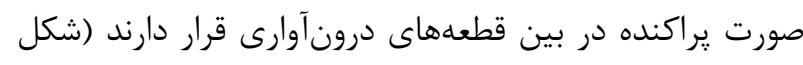

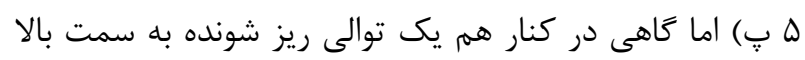

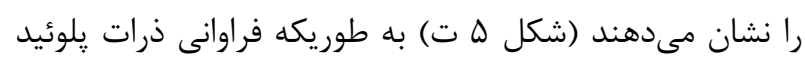

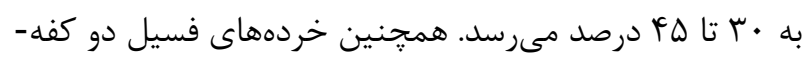

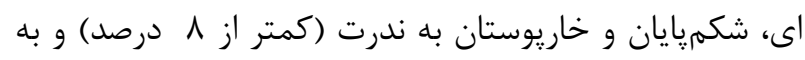

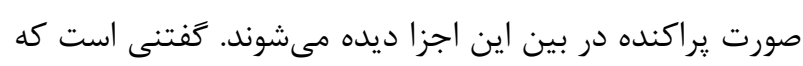

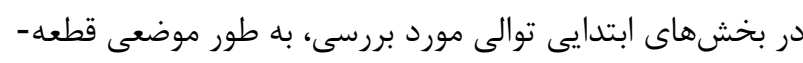

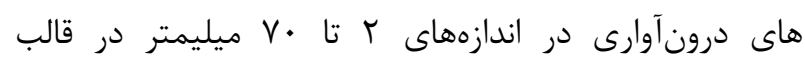

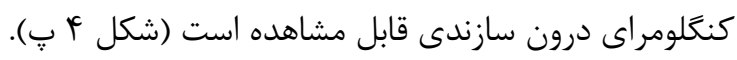

سنغنغارى بررسىهاى صحرايى و ميكروسكويى انجام شده براى سنگ دئى دارى

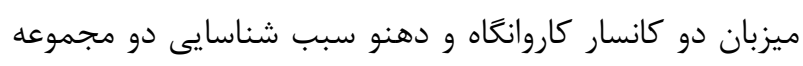

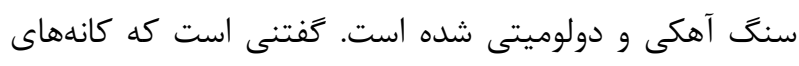

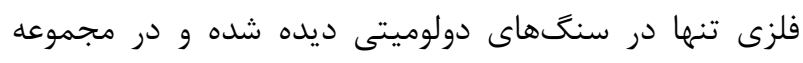

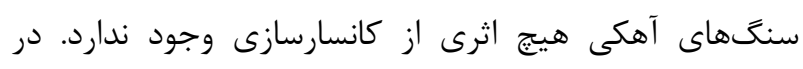
ادامه، هر يك از مجموعههاى سنكى شناسايى شده تشريح اريح توضيح داده مىشوند.

\section{سنغ آهكها}

بررسىهاى ميكروسكويى نشان مى سدهد كه مجموعه رخساره-

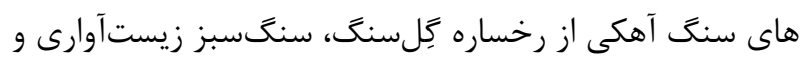

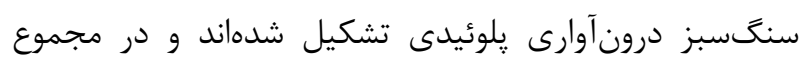

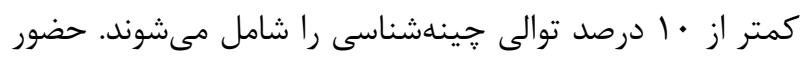

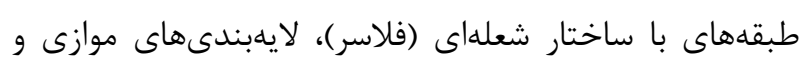

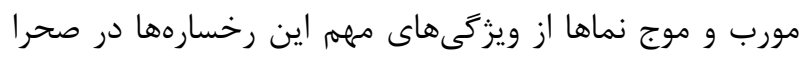
محسوب مىشوند (شكل ع) مورج).

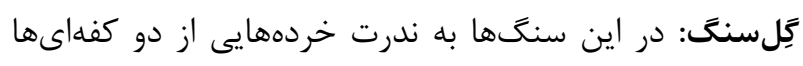

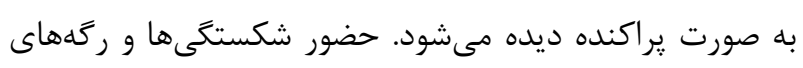

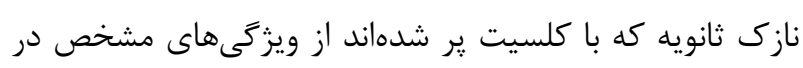
اين رخساره محسوب مىشود (شكل ه الف).

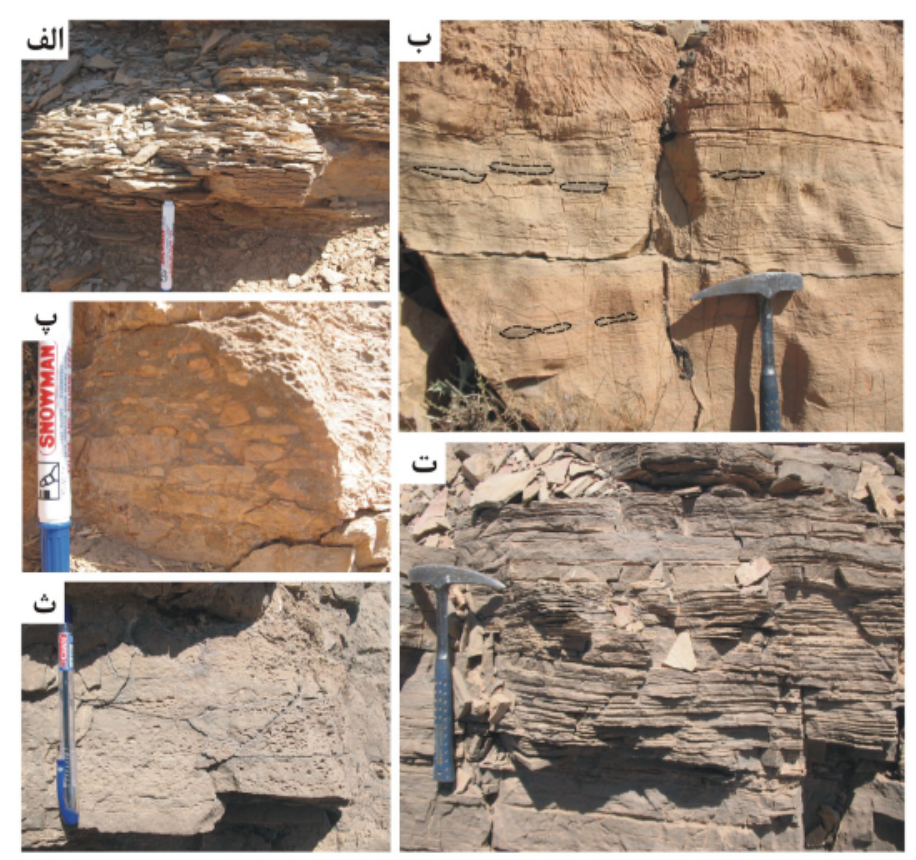

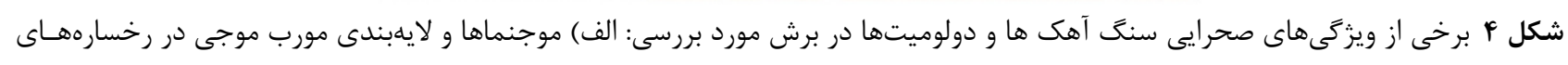

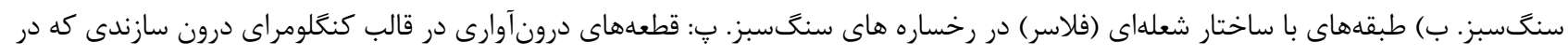

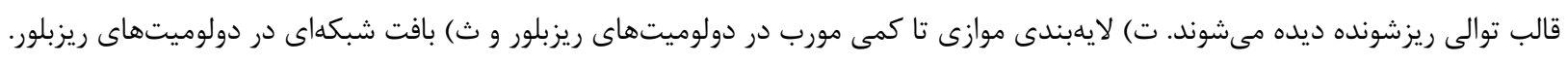



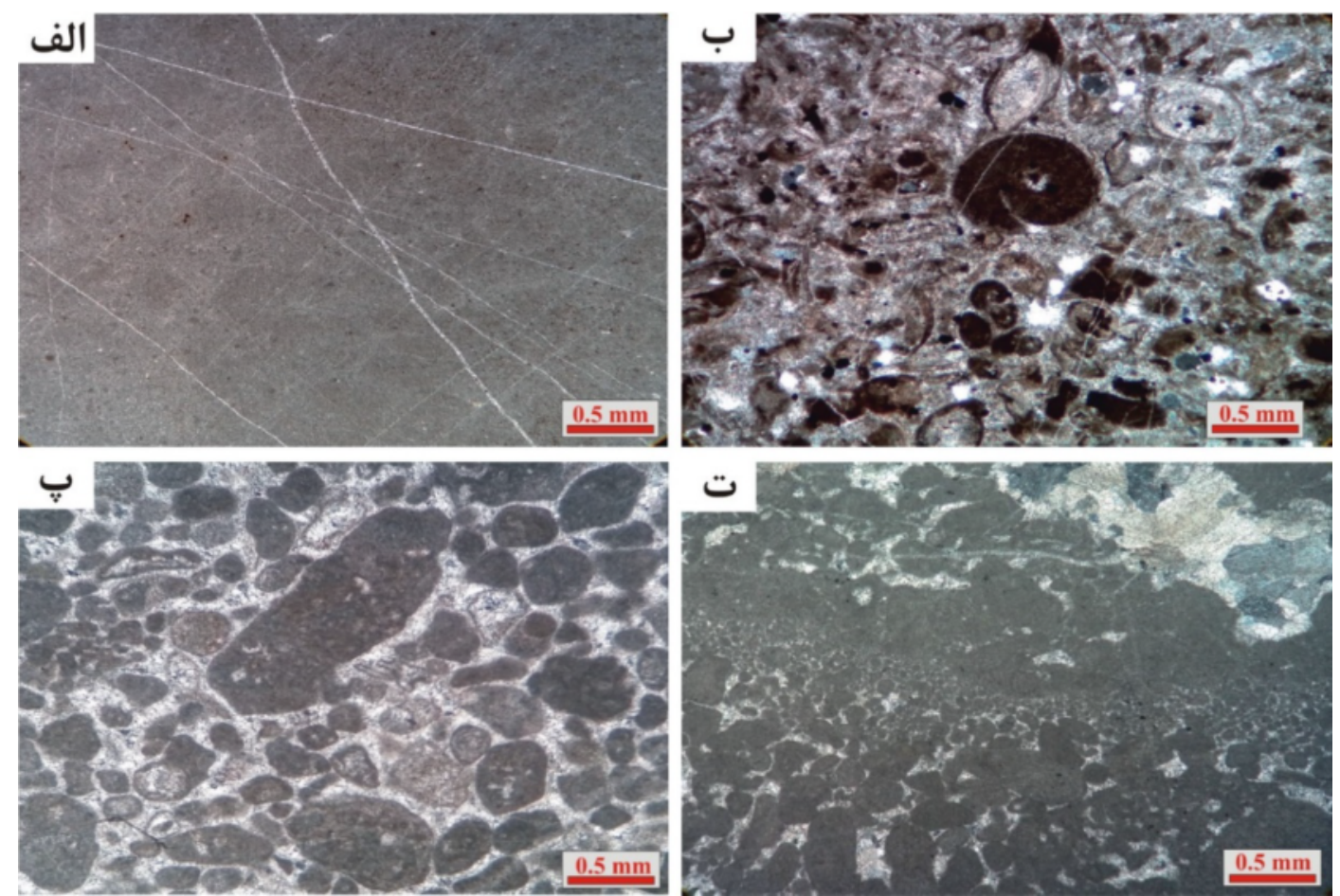

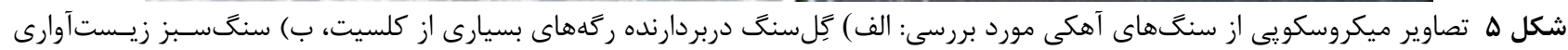

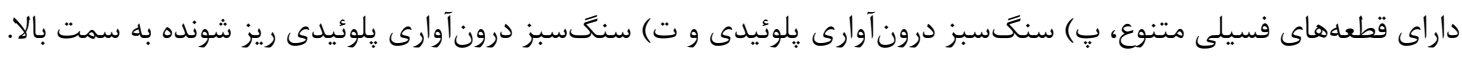

(شكل צ' ب). در تقسيم بندى مرجع [19]، اين دولوميتها از

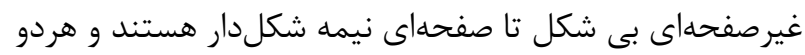

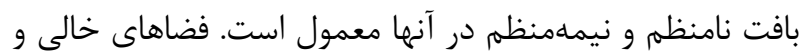

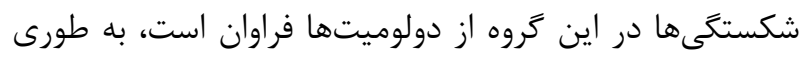

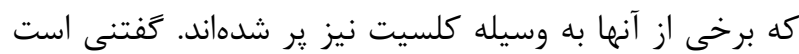

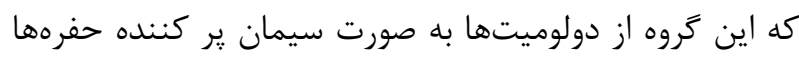

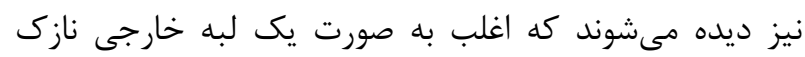
ييرامون حفرههاى تشكيل شده در رخسارههاى آهكى

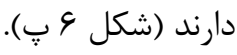
دولوميتهاى متوسط بلور: اين گروه از دولوميتها از از بلورهاى

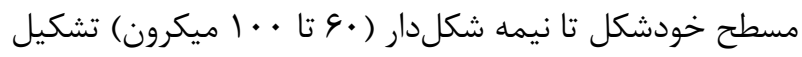

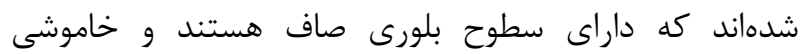

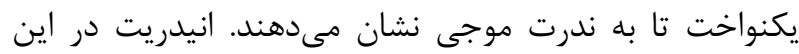

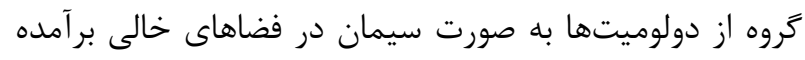

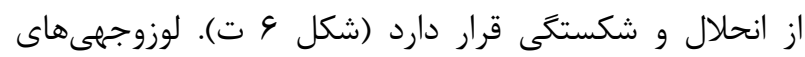

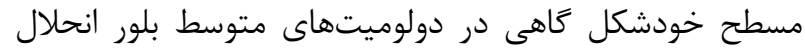

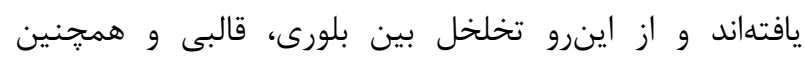

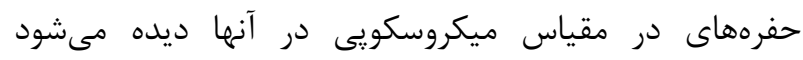

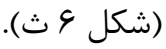

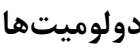

دولوميتها بيش از •9 درصد توالى سنَ ميزبان را شامل شده

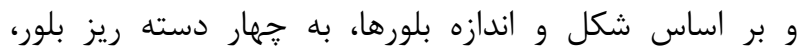

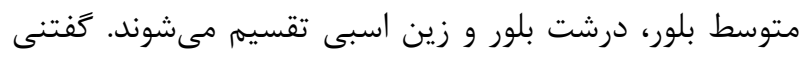

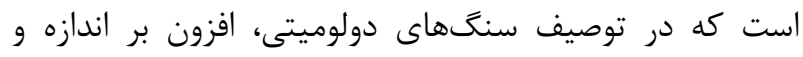

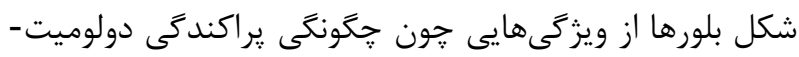
ها، بافت و مرز بين بلورها نيز استفاده شده است.

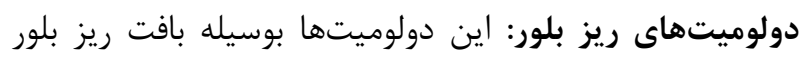

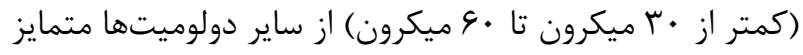

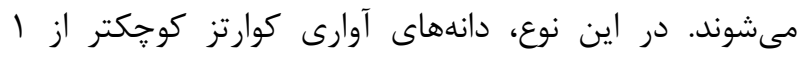

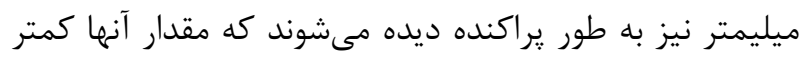

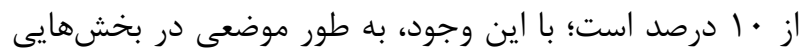

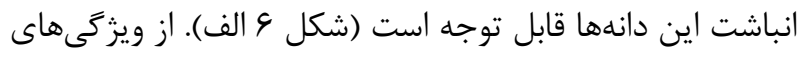

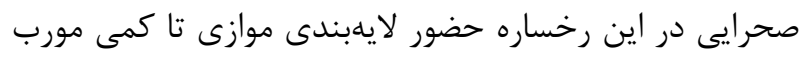

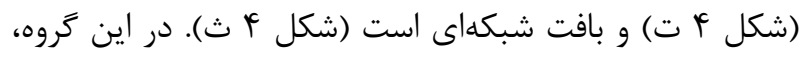

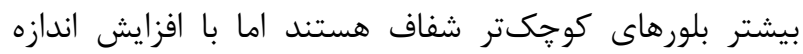
بلورها، سطوح آنها به ويزه در مركز حالت كدر و مه ده آلود نشان

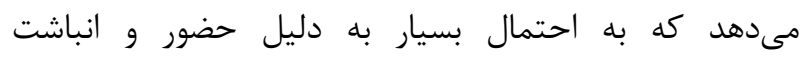
ميانبارهاست. سطوح بين بلورى در برخى از دولوميتهاى اين

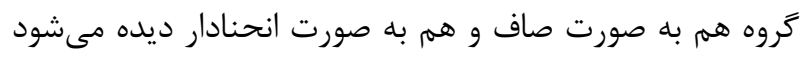



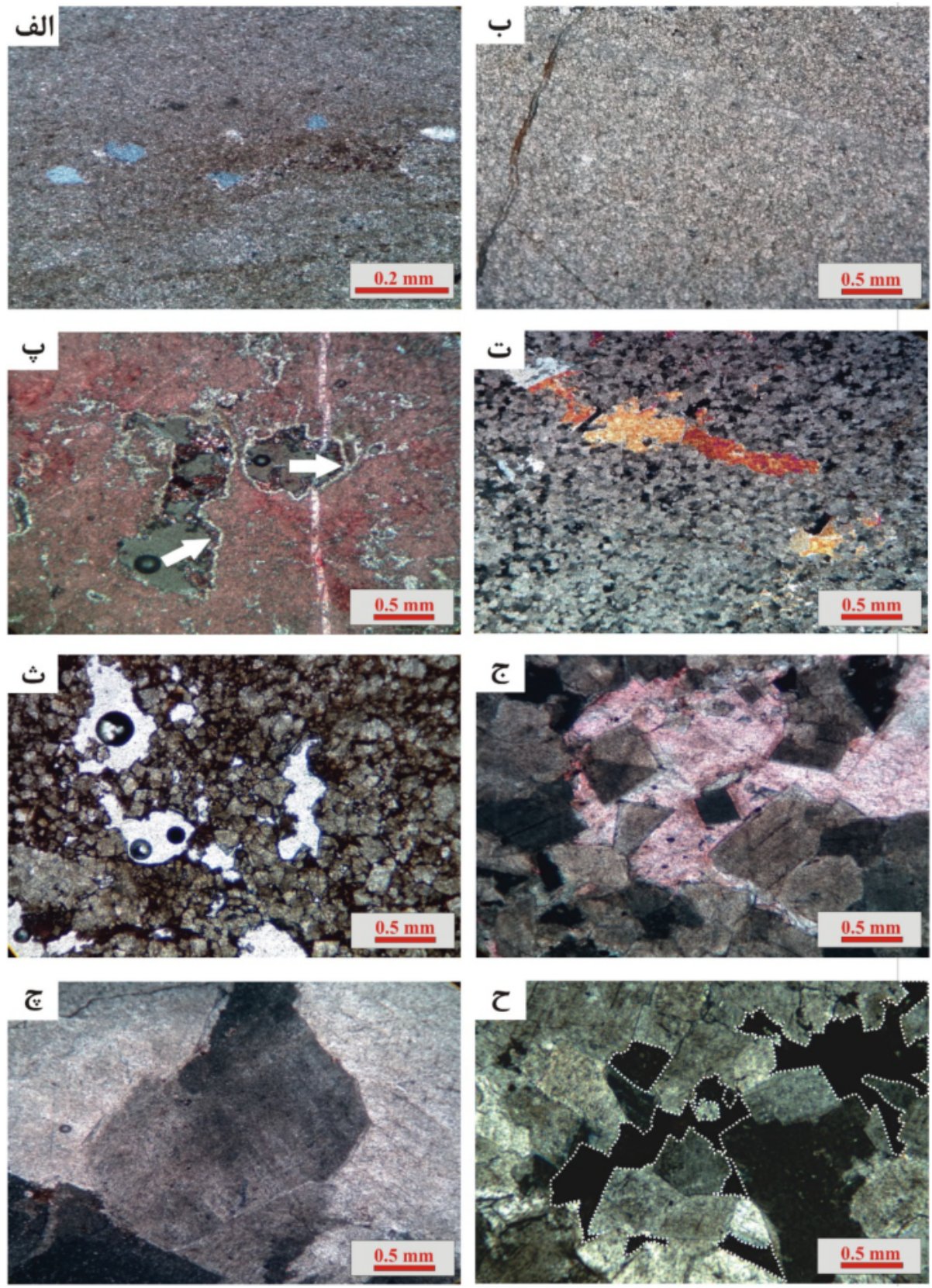

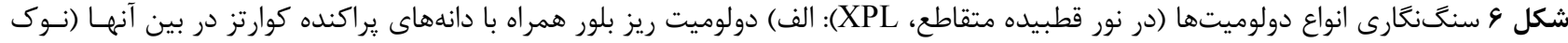

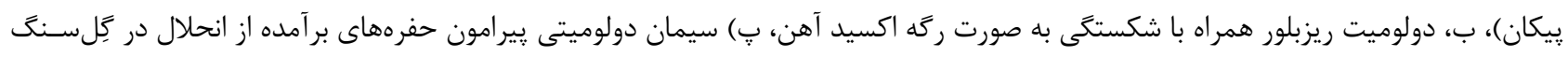

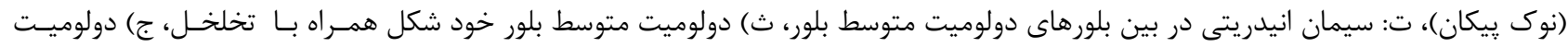

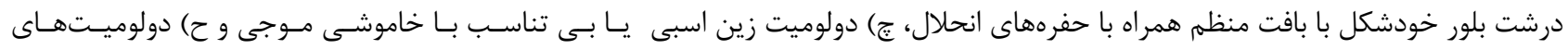
بى تناسب همراه با كانه زايى.

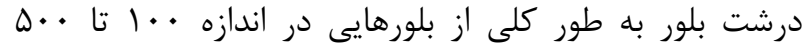
ميكرون تشكيل شدهاند كه به صورت مسطح خود شكل تا نيمه بورس شكلدار (به طور موضعى بىشكل) ديده مىشوند. مرزهاى بين بلورى مستقيم و به ندرت منحنى شكل هستند. بيشتر اين گروه از دولوميتها از نوع صفحهاى شكلدار و غير صفحهاى
دولوميتهاى درشت بلور: دولوميتهاى درشت بلور اغلب به

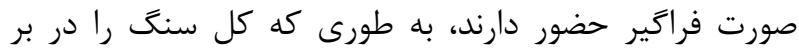

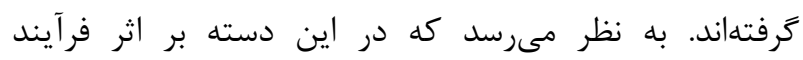

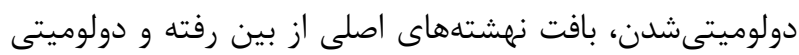

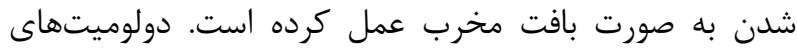


كانسار سرب و روى و بين كانىهايى جون گالن، اسفالريت،

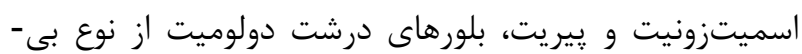
تناسب نيز ديده مىشوند كه به نظر مىرسد كه سازوكار تشكيل آنها در ارتباط مستقيم با محلولهاى كانسارسازى باشد

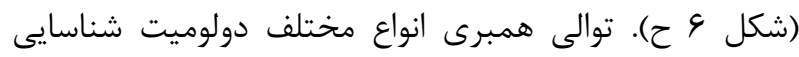
شده در منطقه مورد بررسى در شكل V آورده شده است.

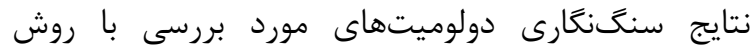

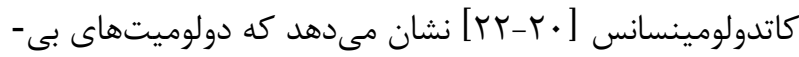
شكل تا نيمهشكلدار به صورت تيره و بدون لومينسانس هستند و تنها يك لبه نازك نارنجى روشن دارند (شكلهاى 1 الف و بهون ب). همجنين زيهنهبندى ناشى از تغيير شرايط شيميايى طى نى تبلور بلور دولوميت در سيمانهاى دولوميتى خودشكل ديده مىشود كه نشاندهنده دست كم سه نسل از رشد بلور است دورئ (شكلهاى 1 بٍ و ت). با اين وجود، بعضى از شكستگى ها و

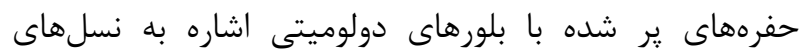

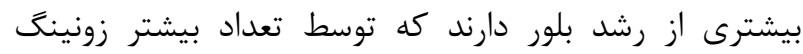
مشخص مىشوند (شكلهاى 1 ث و ج).
نيمه شكلدار است و انواع صفحهاى بى شكل در ميان آنها به ندرت به جشم مى خورد. تقريبا همه بلورها داراى مركز مه آلود و لبه شفاف هستند. خاموشى در اين بلورها به دو صورت يكنواخت و موجى است. هر دو بافت منظم و نامنظم در اين

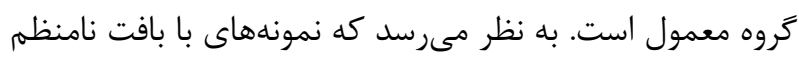
دولوميتهاى نيمه شكلدار تا بى شكل موزائيكى با مرزهاى بلورى نامنظم هستند (شكل \& ع). دولوميتهاى بى تناسب (زين اسبى): دولوميتهاى بـى تناسب يا بهاصطلاح زين اسبى به صورت غير صفحهاى نيمهشكلدار تا بـ

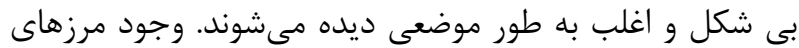

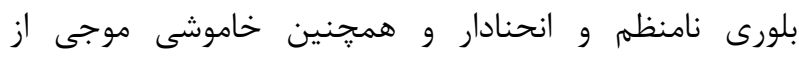
مشخصههاى اصلى اين گروه از دولوميتها محسوب مىشود.

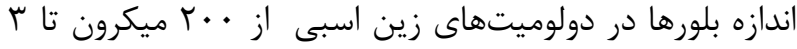

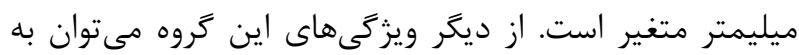
شفافيت بلورها و كاهى وجود ميانبار در آنها اشاره كرد. همجنين در بخشهايى از اين دولوميتها، آثار دولوميتىشدن ديده مىشود. گفتنى است كه ״يرامون ركههاى دربردارنده

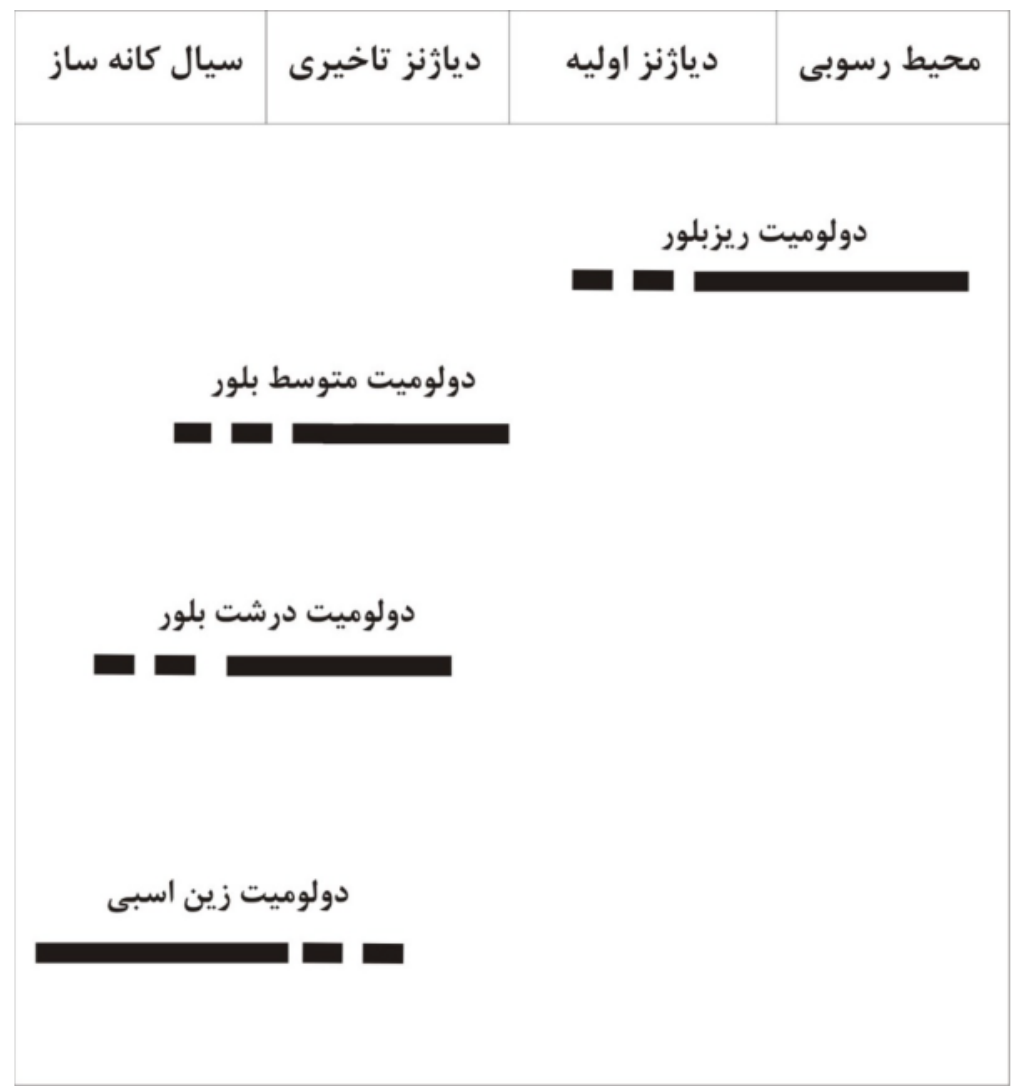

شكل V توالى همبرى دولوميتهاى سازند شترى در منطقه مورد بررسى. 

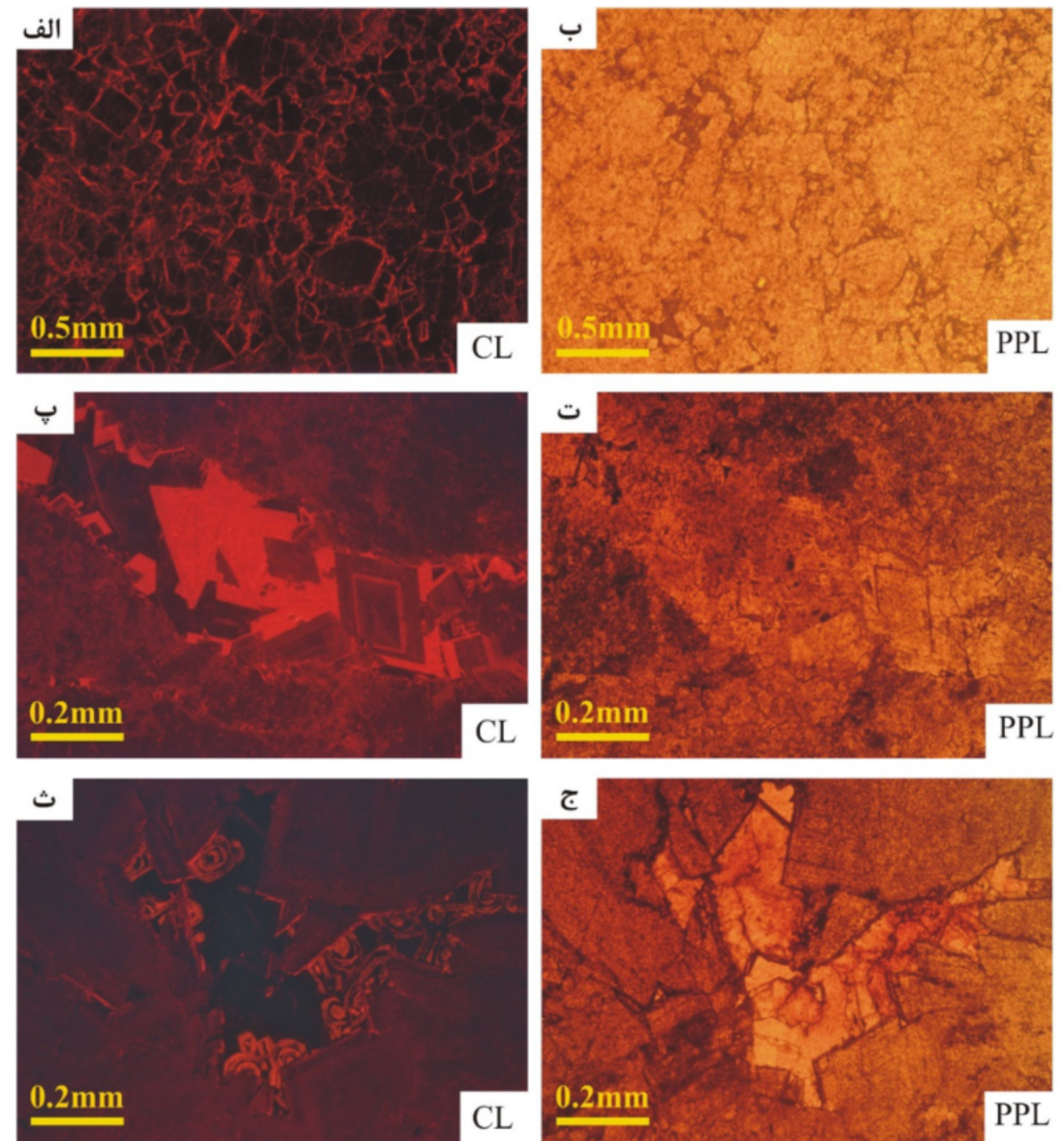

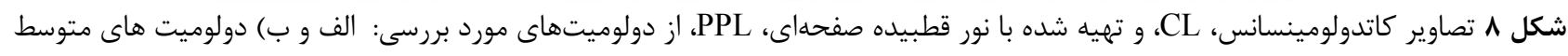

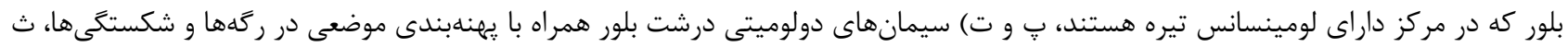

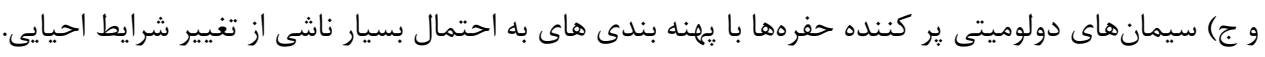

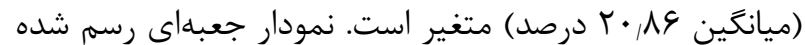
براى اين عنصر نشان مىدهد كه دادههاى مربوط به آن در

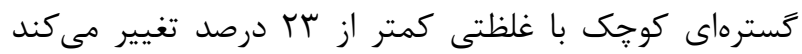

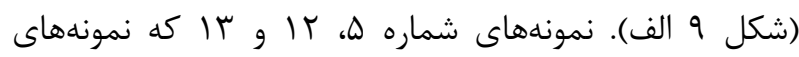

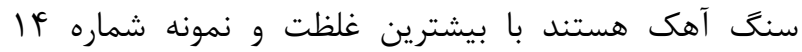
(دولوميت ريزبلور) با كمترين غلظت كلسيه در نمودار جعبهاى به صورت داده يراكنده نشان داده شده است. دليل تهى شدى ركى

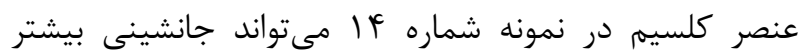
منيزيم و افزايش نسبت منيزم به كلسيهم در آن نسبت به اندازه دازه

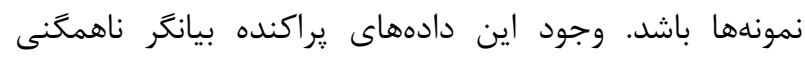
محيط نسبت به كلسيم است.
زمينشيمى

بررسى زمينشيمى سنَ ميزبان كانسارها يكى از راههاى مفيد

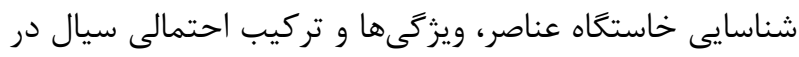

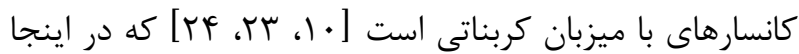
نيز به اين منظور از آن استفاده شد. نتايج تجزيه عناصر سنَ ميزبان (سنگ آهك و دولوميت) در دو معدن كاروانگاه و دهن دهنو

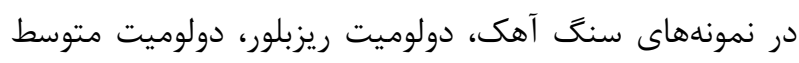
بلور، درشت بلور و زين اسبى در جدول ا ارائه شده است و در ادامه عناصر اصلى و فرعى مهلم جداكانه بيان شدهاند. كلسيم (Ca): مقدار كلسيم در نمونههاى آهكى سنى مئى ميزبان

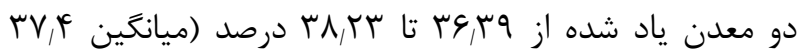

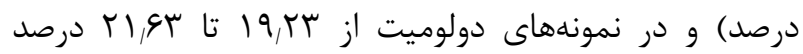




\begin{tabular}{|c|c|c|c|c|c|c|c|c|c|c|c|}
\hline يتروكرافى & شماره نمونه & $\begin{array}{c}\mathrm{Fe} \\
(\mathrm{ppm})\end{array}$ & $\begin{array}{l}\text { Mn } \\
(\mathbf{p p m})\end{array}$ & $\begin{array}{c}\text { Mg } \\
\text { (ppm) }\end{array}$ & $\begin{array}{c}\text { Ca } \\
(\mathrm{ppm})\end{array}$ & $\begin{array}{c}\mathrm{Na} \\
(\mathrm{ppm})\end{array}$ & $\begin{array}{c}\mathrm{Sr} \\
(\mathrm{ppm})\end{array}$ & $\begin{array}{c}\text { Ba } \\
\text { (ppm) }\end{array}$ & $\begin{array}{c}\text { S } \\
\text { (ppm) }\end{array}$ & $\begin{array}{c}\mathbf{P b} \\
(\mathrm{ppm})\end{array}$ & $\begin{array}{c}\mathbf{Z n} \\
(\mathrm{ppm})\end{array}$ \\
\hline \multirow{3}{*}{ سنَ آهك } & $\Delta$ & $r \cdot r \cdot$ & $\checkmark \cdot$ & rF... & тятq.. & $1 \Delta \Delta \cdot$ & $111 / \mathrm{V}$ & IrF. & fF. & AV & rru \\
\hline & IT & rIS. & $v \cdot$ & $r \Delta \Delta \cdot$ & rАrr.. & $1 \ldots$ & THAN & $q$. & $\varphi .$. & $r$ & re \\
\hline & Ir & FAT. & rr. & 999. & rVq... & v. & 191 & $v$. & st. & r & $\Delta f$ \\
\hline ميانكين & - & $r \ldots$ & $1 K \pi / T$ & $\|f\| r / \pi$ & $r V F=g / 9$ & fF. & IVT/9 & $\Delta \ldots$ & $r q 4 / \pi$ & ri & $119 / \pi$ \\
\hline \multirow{4}{*}{ دولوميت ريز بلور } & f & 1919. & 99. & Nrvi. & $1990 .$. & $\Delta q$. & $I T V / T$ & q. & $\psi_{\wedge}$. & 11 & ff \\
\hline & $\wedge$ & irt. & ґА. & $\| r \cdot r V$. & r|बr.. & $\vee \cdot$ & $99 / 7$ & 4. & $r \cdot$. & r & 11 \\
\hline & 1. & FIT. & 10. & 11 FrA. & $19 \Delta T^{\prime}$. & rt. & $11 / 4$ & $\wedge$. & 19. & $r$ & $\Lambda$ \\
\hline & if & $\mid r \Lambda \ldots$ & щ. & १९५. & $19 r 4 .$. & $\Delta 1$. & $11 \% / F$ & $\wedge$. & $f$. & 1. & $4+1$ \\
\hline ميانكين & - & qro. & TAT/Q & NFF. & $r \cdots v \Delta$ & $r F V / D$ & $9 \vee / V$ & $V \vee / \Delta$ & tr. & $9 / 0$ & $I V V / V$ \\
\hline \multirow{3}{*}{ دولوميت متوسط بلور } & r & FIT. & ri. & $|r T T|$. & $r \cdot \psi \wedge .$. & DI. & $1 \cdot f / 1$ & rG. & $\Delta \cdot$ & rq & $r \Delta \cdots$ \\
\hline & 4 & qv. & $\vee \cdot$ & IrqDF. & r|D|.. & $\Delta q$. & $9 T / 9$ & 9. & TH. & 11 & TF \\
\hline & 11 & $q .$. & rr. & $\mu \cdot \lambda$. & $r 19 \ldots$ & rT. & $91 / 0$ & $\wedge \cdot$ & 19. & 1 & 19 \\
\hline ميانگين & - & 1999/V & $r \cdot r / r$ & $\mid$ ITVG|. & r $11999 / \mathrm{V}$ & fF. & $V G / f$ & $\mid F r / T$ & 10. & $I T / V$ & 1191. \\
\hline \multirow{3}{*}{ دولوميت درشت بلور } & v & $1 r q$. & r. & IrqVA. & rIDQ.. & rt. & $91 / 1$ & $v$. & TF. & 1 & v \\
\hline & 9 & 111. & rr. & IrqVT & TIQF.. & rt. & 91 & $\wedge$. & $r .$. & 1 & v \\
\hline & 10 & $\Delta \wedge \vee$. & $\Delta F$. & $|r V q|$. & rira.. & fr. & ITV/G & $v \cdot$ & $r \cdot$. & 11 & 191 \\
\hline ميانگين & - & TNIT/T & re. & $Q \cdot T r \cdot / V$ & TIFFGG/V & rqז/r & $9 \Lambda / 14$ & $V \mu / r$ & TIT/K & $f / r$ & $G \cdot / V$ \\
\hline \multirow{2}{*}{ دولوميت زين اسبى } & 1 & rAS. & lof. & ITETF & $r \cdot 91 .$. & rq. & $|r| /$ & $\wedge$. & TF. & $f$ & \& \\
\hline & r & VVG. & ITH & IrAV.. & rirv. & if. & $r V / T$ & $\wedge$. & Ir. & r & 99 \\
\hline ميانكين & - & DrI. & $\Lambda T I / \Delta$ & $V \cdot 99 \mathrm{~V}$ & rIIVD. & rid & $\Delta * / / \Delta$ & $\wedge$. & 11. & r & 11 \\
\hline
\end{tabular}

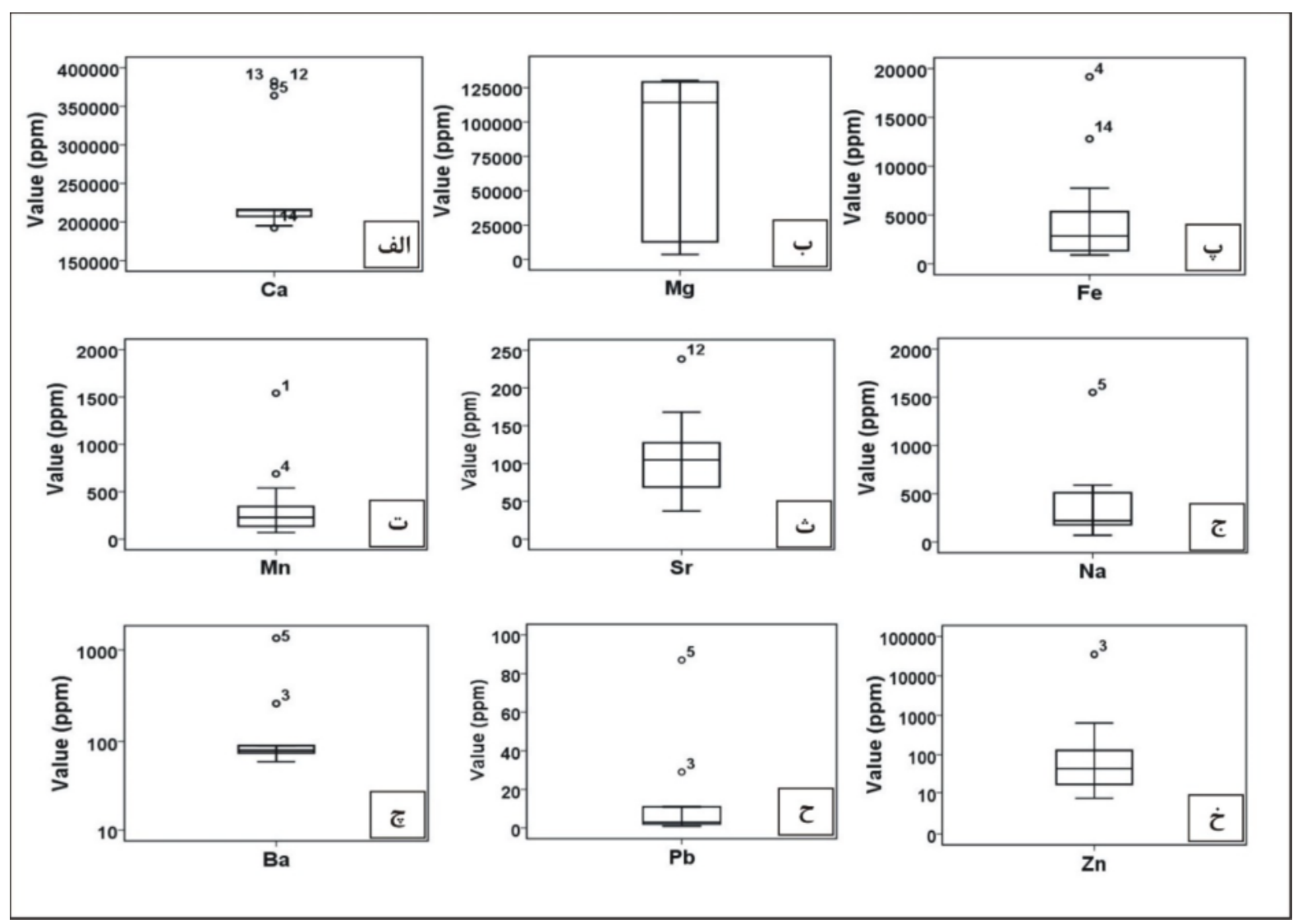

شكل 9 نمودارهاى جعبهاى مهمترين عناصر اصلى و فرعى در سنَ ميزبان كربناتى معادن دهنو و كاروانگاه. 
درصد آنها غلظت كمتر از ه,11 درصد دارند. نبود داده يراكنده در اين نمودار مىتواند نشانگر همگنى محيط براى عنصر منيزيم باشد. شكل · الف الف تغييرات عنصر منيزيم نسبت به مله

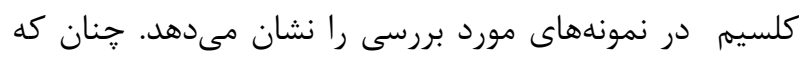
ديده مىشود، سنَهاى آهكى به علت داشتن مقادير بالاى كلسيت از دولوميتها تفكيك شدهاند.
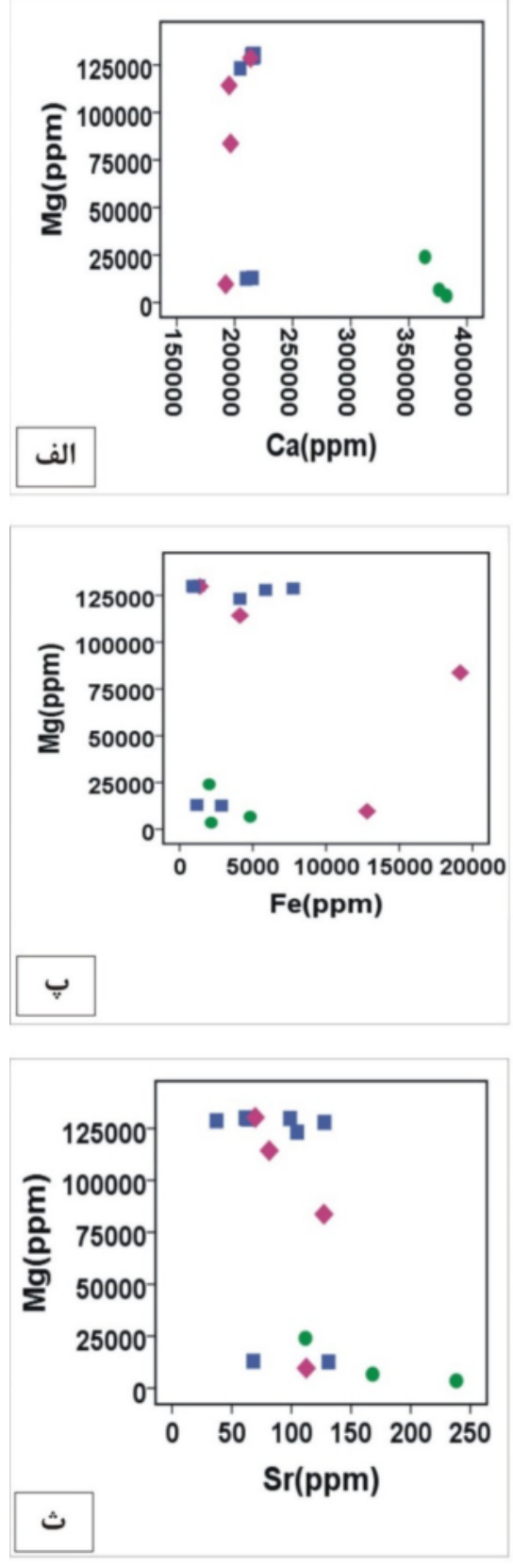

منيزيم(Mg): تمركز عنصر منيزيم در سنگهاى آهكى از هار •

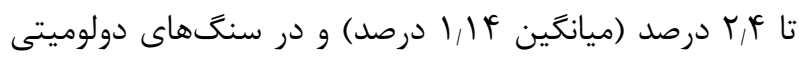

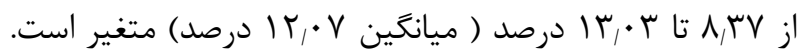
در نمودار جعبهاى مربوط به اين عنصر، يراكندگى و گستره وسيع تغييرات دادهها به خوبى ديده مىشود (شكل 9 بون). درصد دادههاى عنصر منيزيم غلظتى كمتر از سا درصد و
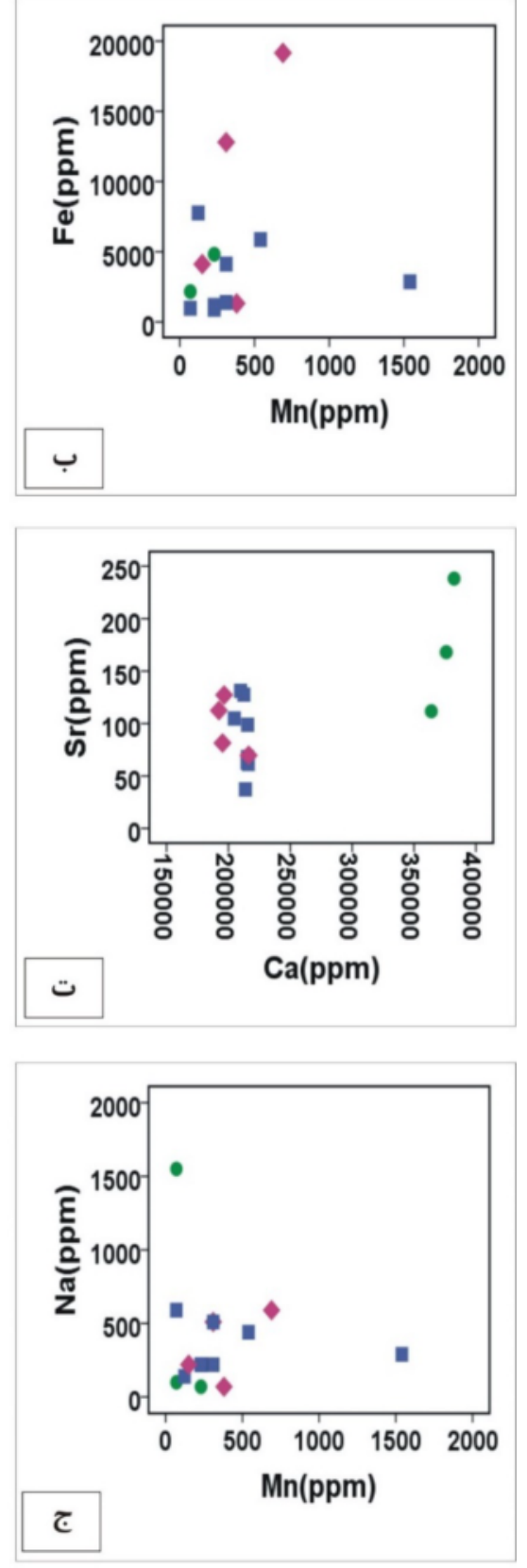

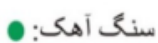

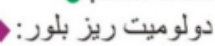

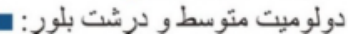

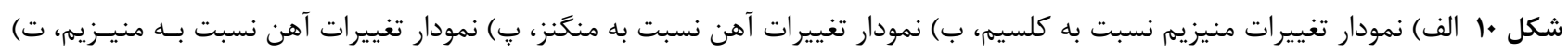

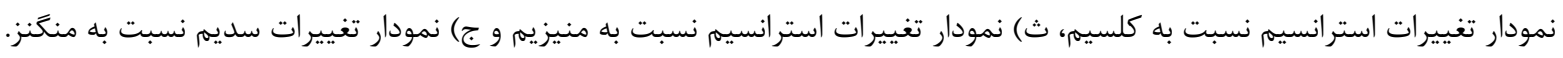


نمودار تغييرات عنصر استرانسيم نسبت به كلسيهم و منيزيم به ترتيب در شكلهاى •l ت و ث ديده مىشود. هر جند كه مقدار استرانسيم با كلسيم در نمونههاى آهكى رابطه مستقيمى و با مقدار منيزيم رابطه عكس نشان مىدهد، اما در انواع دولوميتها روند مشخصى ندارد.

سديم(Na): غلظت عنصر سديم در دولوميتها و سنگ آهك-

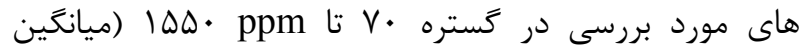

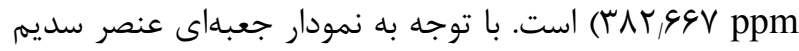
(شكل 9 ج)، • • درصد دادهها گستره تغييرات كمى دارند و

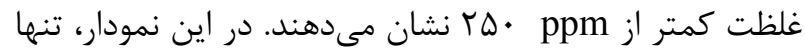

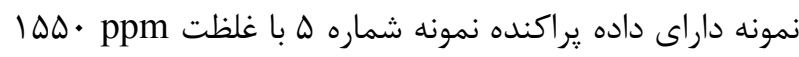

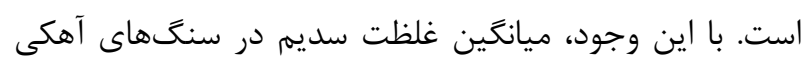
به مراتب كمتر از دولوميتهاست (جدول ()). احتمال حضور يون Na به مقدار زياد در سيال عبورى از اين نمونه سنگ و همجنين همراهى آن با سولفات كلسيه به عنوان عنصر فرعى مىتواند توجيه كننده غنىشدگى نمونه شماره ه از سديم 1. باشد. تغييرات غلظت عنصر سديم نسبت به منحَنز در شكل ج نشان داده شده است كه تقريباً هيج روند معنى دارى ديده نمى شود.

باريم(Ba): غلظت عنصر باريم در نمونههاى مورد بررسى

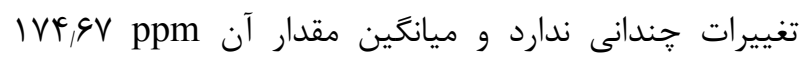
است. به جز دو نمونه شماره ه و ب كه داده يراكنده محسوب مىشوند، غلظت باريم در ساير نمونهها كمتر از است (شكل 9 ج). تمركز بيشتر اين عنصر در نمونههاى مشخص شده نسبت به ساير نمونها مىتواند به دليل همراهى آن با عناصر ديگر مانند سرب باشد. اهميت عنصر باريم در نهشتههاى كربناتى مربوط به محاسبه درجه شورى سيال در محيط است. از نسبت استرانسيم به باريم در دولوميتها مىتوان تا حدى در مورد مقدار شورى محيط در زمان تشكيل آنها اظهار نظر نمود، به طوريكه مقدار Sr/Ba بيش از يك بيانگر

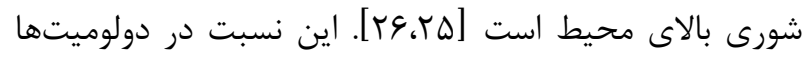
بين 1,1 تا س 1, در تغيير است كه مىتواند نشانكر شورى به نسبت بالاى سيال باشد.

سرب(Pb): مقدار عنصر سرب در نمونههاى سنگ آهك و دولوميت از ا تا NV ppm (ميانگين 1 1,9 ppm) متغير است.
آهن(Fe): مقدار عنصر آهن در دولوميتها و سنگ آهكها در

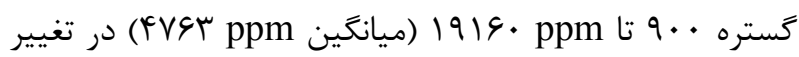
است. يراكندگى كم دادههاى مربوط به غلظت آهن را در نمودار جعبهاى مربوط به آن به خوبى مىتوان ديد (شكل 9 پٍ). دو

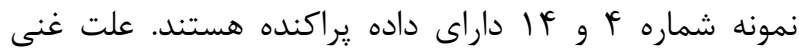
شدكى بيشتر آهن در نمونه شماره f مقدار قابل توجه ساختار اين نمونه دولوميت ريزبلور است كه رنغآميزى به روش مرجع [IV] نيز نشاندهنده اين امر است. همجنين دليل دورئ بالا بودن غلظت اين عنصر در نمونه شماره fl إ وجود اكسيد آهن به صورت سيمان پراكنده و ير كننده رگههاست. در ساير

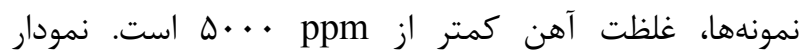
تغييرات عنصر آهن نسبت به دو عنصر منگنز و منيزيم به ترتيب در شكلهاى • ا ب و ״ پ نشان داده شده است. در نمونههاى مورد بررسى، آهن نسبت به منگگنز داراى روند مشخصى نيست، اما تغييرات آهن نسبت به منيزيم تا حدى لـى نشانكر روند افزايشى از سنَ آهك به سمت دولوميتهاى متوسط و درشت بلور است.

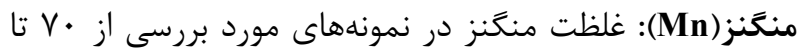

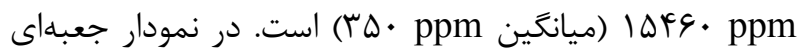
مربوط به اين عنصر (شكل q ت)، به جز دو نمونه شماره ا و F

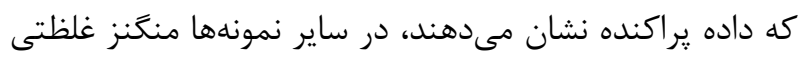

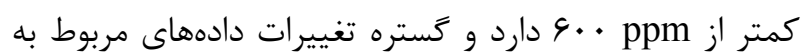
آن جندان وسيع نيست. استرانسيم(Sr): مقدار استرانسيم در نهشتههاى مورد بررسى

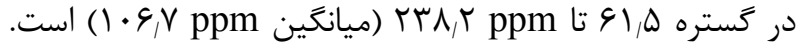
در نمودار جعبهاى اين عنصر، تنها نمونه داراى داده يراكنده نمونه شماره r ا است (شكل 9 ث). وجود فسيلهايى با تركيب يوسته آراگونيتى جون دوكفهاىها در سنگهاى آهكى را مى توان مهرمترين عامل اين غنىشدگى در نظر گرفت. گستره تغييرات دادههاى مربوط به اين عنصر در ساير نمونهها را در نمودار جعبهاى به خوبى ديده مىشود. بر اساس اين نمودار،

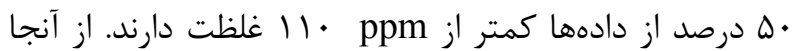
كه مقدار استرانسيم با غلظت كلسيم رابطه مستقيم و با مقدار منيزيم رابطه عكس دارد [ץT]، بيشترين تمركز اين عنصر با مآ

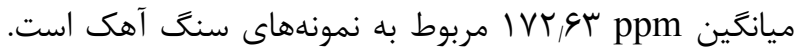


است كه نشان دهنده نبود كميلكسهاى سولفيدى سرب و روى در نمونههاى مورد بررسى است. به اين ترتيب، مقادير بالاى عنصر روى در نمونههاى ب و له و عنصر سرب در نمونه شماره ه مىتواند نشان دهنده رسوبگذارى اين عناصر به صورت تركيب كربناتى (انواع كانىهاى كربنات روى) باشد. همبستخى مثبت گوگرد با عنصر كلسيم در نمونههاى مورد بررسى به احتمال بسيار به دليل حضور سولفات كلسيم و به ويزه تشكيل انيدريت در اين سنگهاست. گفتنى است كه هيج ارتباط مشخصى بين دو عنصر استرانسيم و گتوزرد در نمونهها تشخيص داده نشد و به احتمال بسيار علت نشان دادن

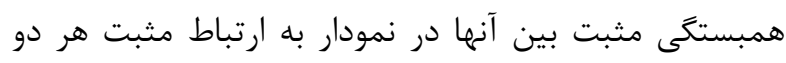
عنصر با كلسيم بر مى گردد. عناصر خاكى نادر (REE): عناصر خاكى نادر به علت تحركيذيرى هايين ابزار مفيدى براى شناسايى خاستغاه سيالها محسوب مىشوند، به طورى كه آبهاى جوى بر تركيب و توزيع عناصر خاكى نادر در سنَهاى كربناتى (سنَ آهك و دولوميت) كمترين اثر را دارند و اين عناصر تا حدى دستخوش سيستمهاى درونزادى و برهمرنش سيال- سنگ مىشوند

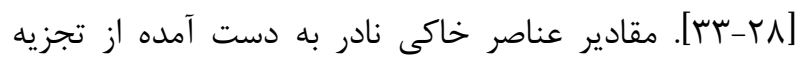
نمونههاى مورد بررسى در جدول ب آورده شده است. بهنجارش

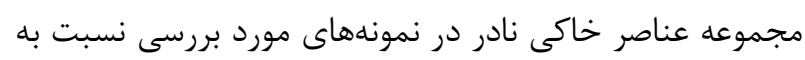

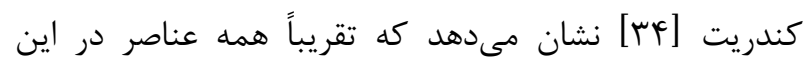
نمونهها نسبت به كندريت غنىشدگى دارند، اما روند تغييرات عناصر نشان مىدهد كه عناصر خاكى نادر سبك (LREE)

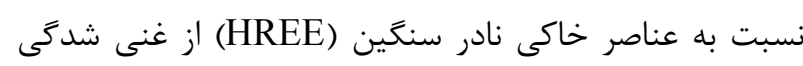
بيشترى برخوردار هستند (شكل ||(1). اين روند تقريباً يكسان در همه نمونههاى سنگ آهك و دولوميت ديده مىشود كه اين امر گواهى بر خاستخاه يكسان عناصر خاكى نادر در نمونههاى سنگ ميزبان است. در نمودار تغييرات عناصر خاكى نادر،

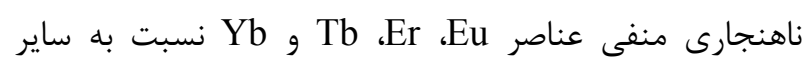
عناصر نشان دهنده تحرك ڤذيرى كمتر آنها در شرايط محيطى

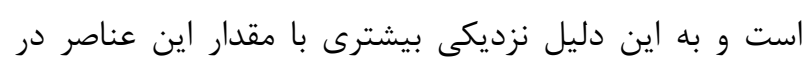

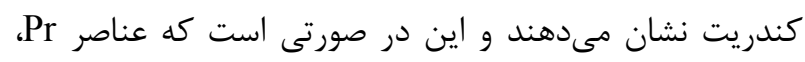
Gd واراى ناهنجارى مثبت هستند. Gd
با توجه به اينكه مقدار كلارك اين عنصر در سنگهاى كربناتى

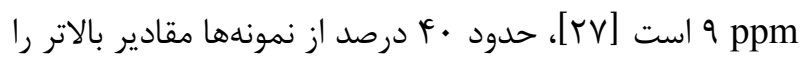
نشان مىدهند. دو نمونه شماره ه و r در نمودار جعبهاى به صورت داده يراكنده نمايش داده شده (شكل 9 ح). اين غنى شدكى از سرب در نمونه نام برده مىتواند به دليل حضور

$$
\text { تركيبات كربناتى سرب باشد. }
$$

روى(Zn): گستره تغييرات غلظت عنصر روى در نمونههاى

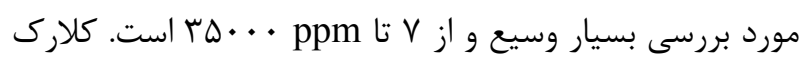

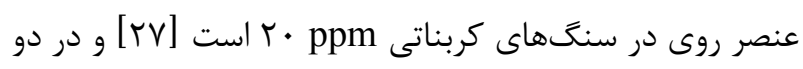
سوم نمونهها، مقدار روى بالاتر از كلارك است. نمونه شماره r تنها نمونه داراى داده يراكنده در نمودار جعبه مربوط به فلز روى است (شكل 9 خ). با توجه به اين نمودار، يراكندگى دادههاى مربوط سرب در ساير نمونها تقريبا يكنواخت است. حضور رگههايى از ماده معدنى به صورت سيمان در نمونه شماره r ديده مىشود كه به احتمال بسيار به دليل غنى بودن اين نمونه از روى است. نمودار ضريب همبستخى عناصر اصلى و فرعى: به نظر مىرسد

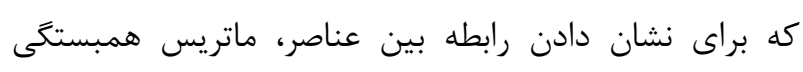

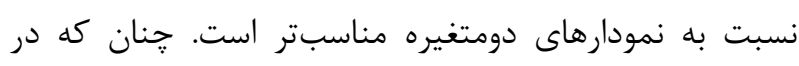
جدول r مشخص است، همبستخى دو عنصر كلسيم و منيزيم در نمونهها منفى است. اين امر آشكارا به دليل دولوميتى بودن • ^ درصد از نمونههاست كه با افزايش مقدار منيزيم در آنها كلسيم كاهش يافته است. بيشترين همبستكى مثبت بين دو عنصر باريم و سرب با مقدار 9VD, • وجود دارد. همجنين سديم با دو عنصر باريم و سرب نيز همبستخى مثبت بالايى نشان مىدهد. علت اين همبستكى را مىتوان حضور همزمان اين عناصر در يك سيال دانست كه با ايجاد شرايط مساعد رسوبخذارى در تركيب سنگ ميزبان قرار گرفتهاند. افزون بر اين، عنصر

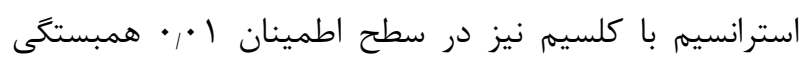
مثبت دارند، در صورتى كه همبستكى آن با منيزيم در سطح اطمينان ه • • • منفى است. علت اين امر تمايل عنصر استرانسيم

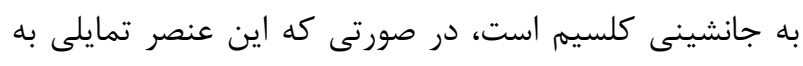
جانشينى منيزيم ندارد. نكته قابل توجه نبود همبستخى شديد

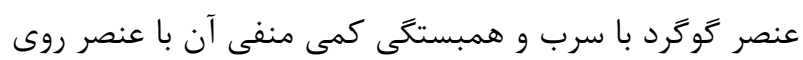


جدول r ماتريس همبستخى بين عناصر اصلى و مههمترين عناصر فرعى در دولوميتها.

\begin{tabular}{|c|c|c|c|c|c|c|c|c|c|c|}
\hline & Ca & Mg & $\mathrm{Fe}$ & Mn & $\mathrm{Na}$ & $\mathrm{Sr}$ & Ba & S & $\mathbf{P b}$ & Zn \\
\hline Ca & 1 & & & & & & & & & \\
\hline Mg & $-\Delta \varphi \varphi^{x}$ & 1 & & & & & & & & \\
\hline $\mathbf{F e}$ & $-r, r \Delta V$ & $-\cdot 19$ & 1 & & & & & & & \\
\hline Mn & - . TTV & $-\cdot, \backslash \vee \Lambda$ & $\cdot, r \cdot \Delta$ & 1 & & & & & & \\
\hline $\mathbf{N a}$ & $-0,199$ & $-0,1 \mathrm{Fr}$ &.$/ 118$ & $-\cdot .90$ & 1 & & & & & \\
\hline $\mathrm{Sr}$ &.,$g V I^{x \times}$ & $-\cdot 4 \cdot \Delta^{x}$ & $\cdot\|\|^{\mathrm{F}}$ & $\cdot|| f \mid$ & $-\cdot \cdot \cdot T T$ & 1 & & & & \\
\hline Ba & - 1499 &,$- K M Y$ & $-0,1\} \&$ & $-\cdot, r \mid f$ & - $\wedge \Lambda \Lambda^{\times x}$ & ו ו & 1 & & & \\
\hline $\mathbf{S}$ & - $\gamma \mathrm{V} q^{\mathrm{xx}}$ & - IFFF & $\cdot 1.4$ & $-\cdot \cdot r$ & $\cdot 1 \Delta \varphi$ & - $\Delta V \varphi^{c^{x}}$ & - TET & 1 & & \\
\hline $\mathbf{P b}$ & - rar & $\cdot, 1 \Lambda$. & $-\Delta \mid$ & $-\cdot, 1 \wedge$. & - $9 \mathrm{rr}^{\mathrm{xx}}$ & $\cdot \cdot \varphi \Delta$ & - $9 \vee \Delta^{x x}$ & $\cdot r \cdot V$ & 1 & \\
\hline Zn & $\cdot \| \& \wedge$ & $\cdot \pi \mid r$ & $-\cdot \cdot \cdot T V$ & $-\cdot \cdot \cdot \mu \cdot$ & $\cdot 1 \cdot r$ & .1 .9 & -, $\mathrm{V}$ & ת TKM & $\cdot \pi T \cdot$ & 1 \\
\hline
\end{tabular}

جدول ب دادههاى برآمده از تجزيه عناصر خاكى نادر در نمونهاى سنگ ميزبان معادن دهنو و كاروانگًا.

\begin{tabular}{|c|c|c|c|c|c|c|c|c|}
\hline يتروكرافى & شماره & $\begin{array}{c}\text { La } \\
(\mathbf{p p m})\end{array}$ & $\underset{(\mathbf{p p m})}{\mathrm{Ce}}$ & $\begin{array}{c}\operatorname{Pr} \\
(\mathbf{p p m})\end{array}$ & $\begin{array}{c}\text { Nd } \\
(\mathbf{p p m})\end{array}$ & $\underset{(\mathbf{p p m})}{\mathrm{Sm}}$ & $\underset{(\mathbf{p p m})}{\mathbf{E u}}$ & $\underset{(\mathbf{p p m})}{\mathbf{G d}}$ \\
\hline \multirow{3}{*}{ سنَ آهى } & $\Delta$ & $r$ & 11 & ז, II & $\Lambda, r$ & $1,9 r$ & $\cdot t^{f}$ & $1 \cdot v$ \\
\hline & $1 \pi$ & $\Delta$ & 10 & r/Vq & 9,9 & 1,199 &.,$\pi 9$ & $1, r \Lambda$ \\
\hline & r & $r$ & 1. & T,YG & $\Lambda, r$ & $1, \Delta T$ &.$/ r$ & $1 \cdot v$ \\
\hline \multirow{4}{*}{ دولوميت ريزبلور } & r & 11 & rq & $f, F$ & 19,9 & $r, r_{1}$ & $\cdot \Delta F$ & $T, Y$ \\
\hline & $\Lambda$ & 1 & 9 & $r, 19$ & $V_{j} V$ & $1, f \Delta$ & .11 & $1, \cdot 1$ \\
\hline & 1. & f & IT & T,GH & 9 & 1,19 & r & $1, \pi 9$ \\
\hline & If & $\wedge$ & rI & $r, g r$ & r & $r, \Delta F$ & - זq & 1,91 \\
\hline \multirow{3}{*}{ دولوميت متوسط بلور } & $r$ & 1 & 9 & T,lY & $V_{\gamma} \wedge$ & $1,4 \lambda$ & .110 & 1 \\
\hline & 9 & 1 & 9 & $r, 1 T$ & $V, V$ & $1,4 \pi$ & .11 & .99 \\
\hline & 11 & 1 & 9 & $r, 1 r$ & $V_{1} g$ & $1, f$ & .11 & .99 \\
\hline \multirow{3}{*}{ دولوميت درشت بلور } & $V$ & 1 & 1. & $r, I V$ & $V_{\gamma} \wedge$ & $1, f y$ & 0,11 & .99 \\
\hline & 9 & 1 & 1. & T,le & $V_{\gamma / \Lambda}$ & $1, F T$ & .11 & $1, \cdot 1$ \\
\hline & 10 & $r$ & 1. & T,YA & $\Lambda, r$ & $1, \Delta 9$ & .11 & 1,11 \\
\hline \multirow{2}{*}{ دولوميت زين اسبى } & 1 & $r$ & $\pi$ & $r, \pi 9$ & $\Lambda, \Delta$ & $1, \Delta V$ & .14 & 1,1 \\
\hline & $r$ & $r$ & 1. & T,T & 9 & 1,99 & $\cdot \pi \Delta$ & 1,49 \\
\hline يتروكرافى & شمونه & $\begin{array}{c}\text { Tb } \\
(\mathbf{p p m})\end{array}$ & $\begin{array}{c}\text { Dy } \\
(\mathbf{p p m})\end{array}$ & $\underset{(\mathbf{p p m})}{\mathbf{E r}}$ & $\underset{(\mathbf{p p m})}{\mathbf{T m}}$ & $\begin{array}{c}\text { Yb } \\
(\mathbf{p p m})\end{array}$ & $\underset{(\mathbf{p p m})}{\mathbf{L u}}$ & $\underset{(p p m)}{Y}$ \\
\hline \multirow{3}{*}{ سنَ آهك } & $\Delta$ & .1 .9 & $\cdot \wedge \vee$ & $\cdot r$ & .111 & $\cdot \mu^{r}$ & .1 .9 & $f, 8$ \\
\hline & IT & $0,1 f$ & $1, \cdot 9$ & $\cdot \pi \Lambda$ & .11 & $\cdot \Delta$ & $\because \cdot V$ & $\Delta, \Delta$ \\
\hline & $1 \pi$ & $\cdot \cdot v$ & $\cdot \wedge \Delta$ & $\cdot \pi \Delta$ & .11 & $\cdot \mu^{r}$ &., 19 & $f, \Delta$ \\
\hline \multirow{4}{*}{ دولوميت ريزبلور } & r & $\cdot x^{4}$ & $r, r$ & $1, \cdot r$ & .119 & $\cdot \wedge$ & .1 & 1. \\
\hline & $\wedge$ &. .99 & $\cdot \Delta r$ & 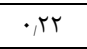 & .11 & $\cdot r$ & $\cdot \cdot 1$ & $p, r$ \\
\hline & 1. & $\because \cdot 1$ & 1,11 & $\cdot i^{4}$ & .111 & $\cdot \pi$ & .1 .9 & $\Delta, r$ \\
\hline & If & - Mr & $1,9 \mathrm{~V}$ & - $A T$ &.$/ \mathrm{V}$ &., 9 & .1 .9 & $\wedge$ \\
\hline \multirow{3}{*}{ دولوميت متوسط بلور } & $r$ & $\cdot . \cdot 9$ & $\cdot \wedge \Delta$ & $\cdot r \Delta$ & 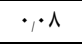 & $\cdot r$ &..$\cdot 9$ & $f, f$ \\
\hline & 9 & $\cdot \cdot 1$ & $\cdot \lambda F$ & 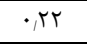 & $\cdot \cdot \wedge$ & $\cdot r$ & $\because \cdot V$ & $f, r$ \\
\hline & 11 & $\cdot \cdot \cdot 1$ & $\cdot 111$ & . & $\cdot .9$ & $\cdot r$ & $\cdot \cdot V$ & $f, r$ \\
\hline \multirow{3}{*}{ دولوميت درشت بلور } & V & $.1 \cdot 9$ & $\cdot 11$ & . TY & $\cdot 11$ & $\cdot r$ & $\cdot .9$ & $\varphi, r$ \\
\hline & 9 &. .99 & $\cdot \lambda r$ &.$\pi t$ & .1 .9 & $\cdot r$ &..$\cdot 9$ & $f, r$ \\
\hline & 10 & $\cdot \bullet \wedge$ & $\cdot \wedge \Lambda$ & $\cdot \pi \Delta$ & .111 & $\cdot \pi$ & .1 .9 & $r, 8$ \\
\hline \multirow{2}{*}{ دولوميت زين اسبى } & 1 & $\cdot, 1$ & $\cdot 9$ & $\cdot, r \Lambda$ & .11 & $\cdot \pi$ &. .99 & $r \cdot 1$ \\
\hline & $r$ &., $1 V$ & 1,19 &., 49 &.$/ 1 r$ & $\cdot \mu^{k}$ &. .99 & 9 \\
\hline
\end{tabular}




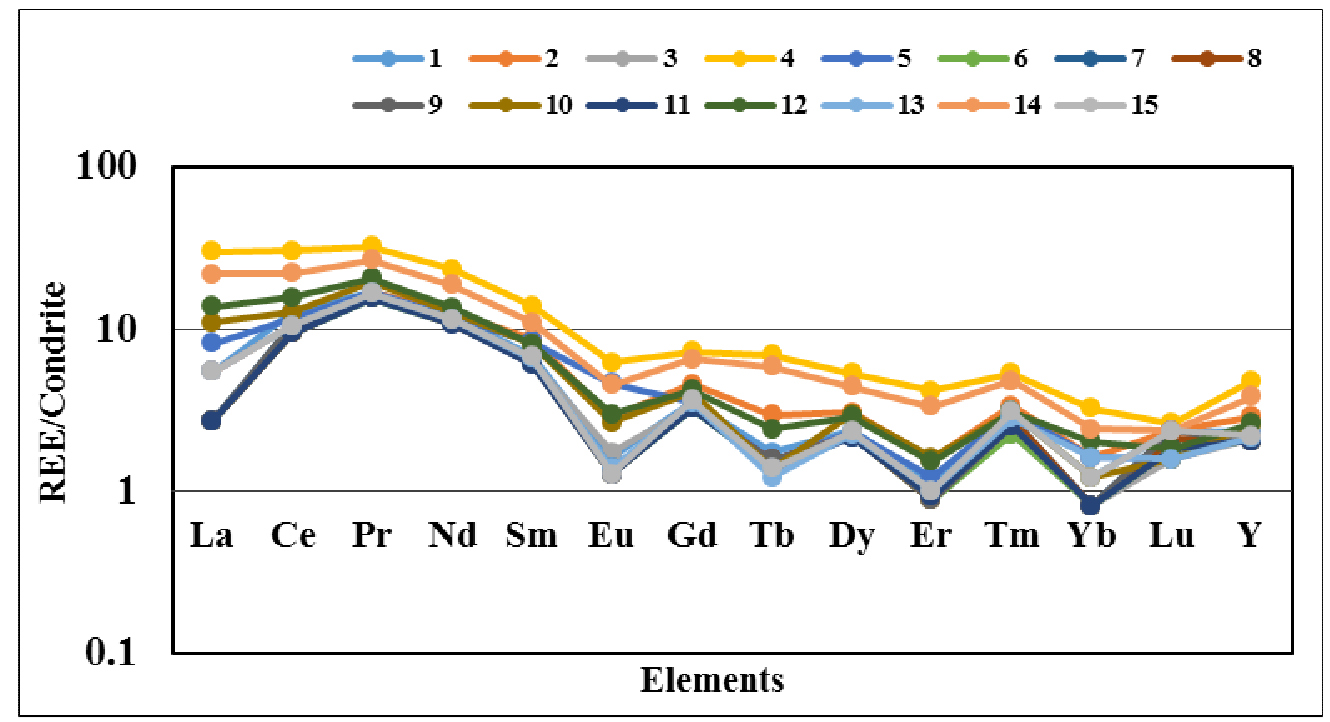

شكل II نمودار عنكبوتى عناصر خاكى نادر بهنجار شده به كندريت [بr].

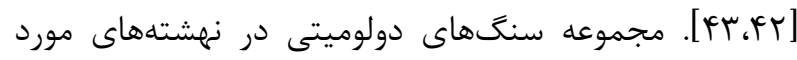

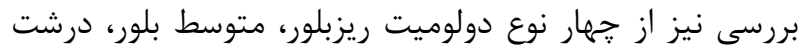

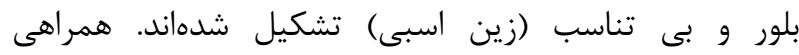
رخسارههاى دولوميتى ريزبلور با مجموعه رخسارههاى آهكى،

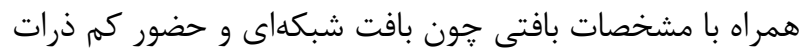

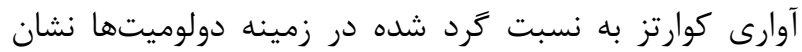

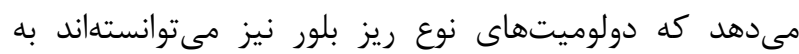

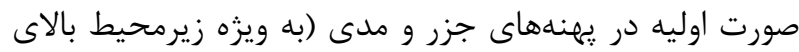

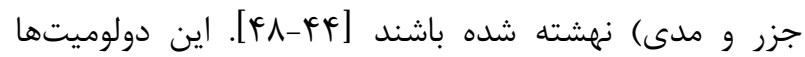

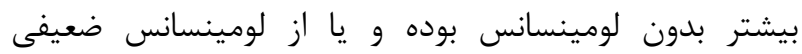
برخوردار هستند كه بازتاب كننده شرايط اكسيد كننده محيط لونيط

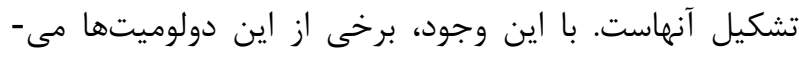

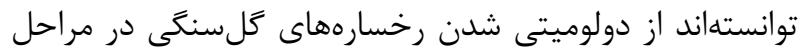

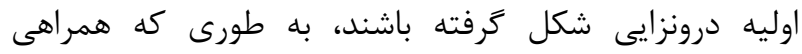

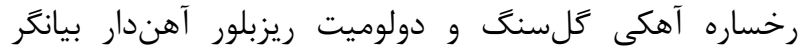

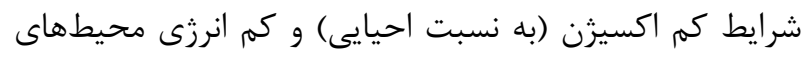

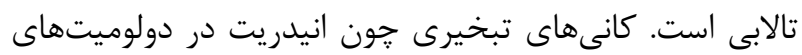

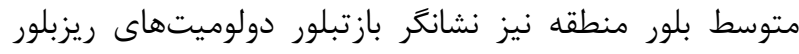

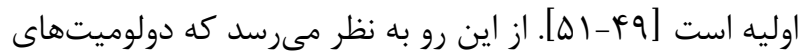

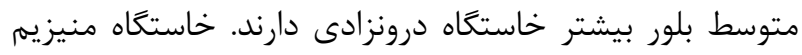

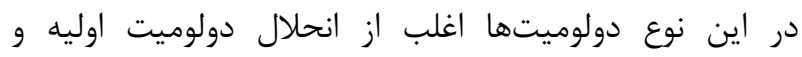

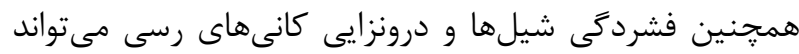

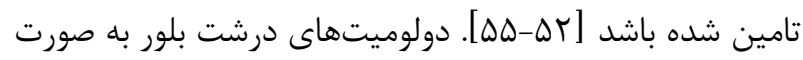
فراگير و به شكل مسطح خود شكل تا نيمه شكلدار ديده مئ-

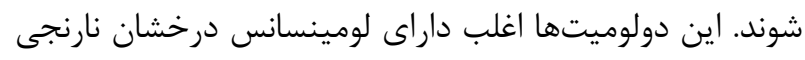

برداشت

بررسى رخسارهها، زمينشيمى و شرايط تشكيل سنگ ميزبان

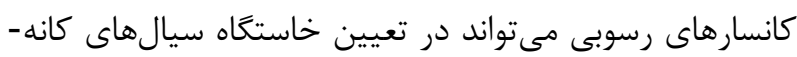

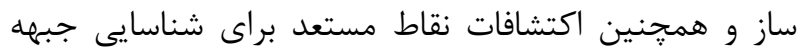

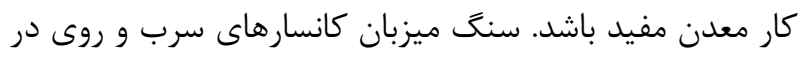

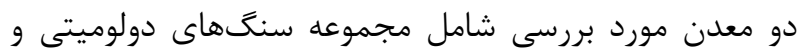
آهكى وابسته به سازند شترى (ترياس ميانى) است. كانسار

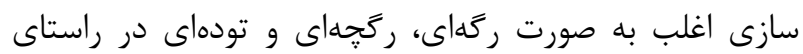

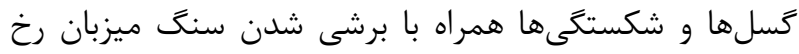

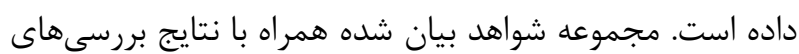

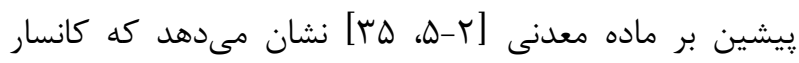

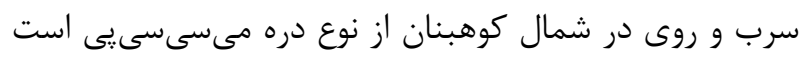

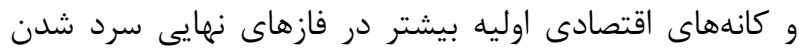

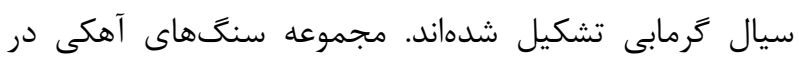

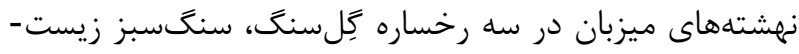

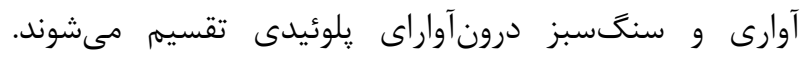

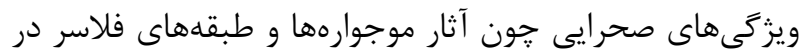

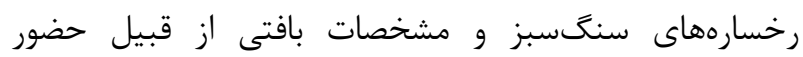

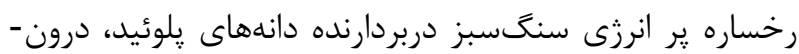

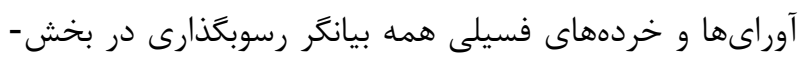

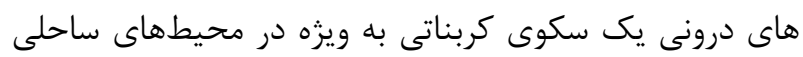

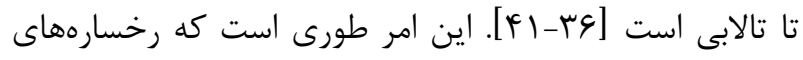

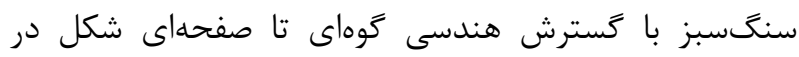
محيط جزرومدى تا خط ساحلى و بيشتر رخسارهماى كل

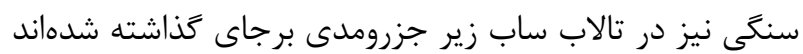




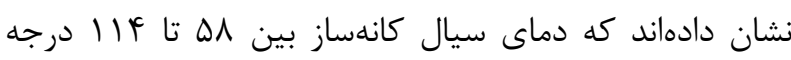

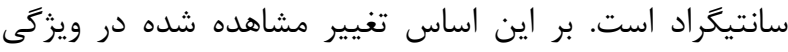

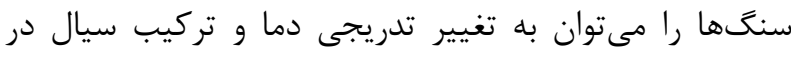

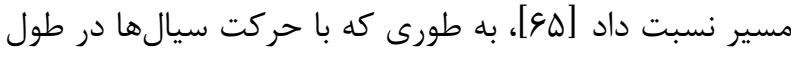

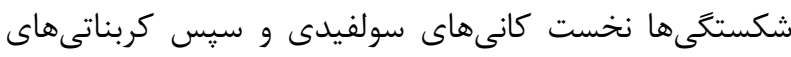

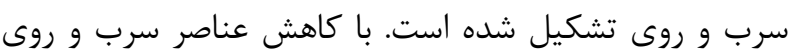

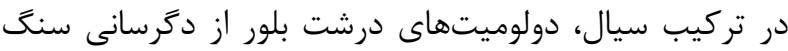

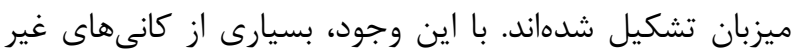

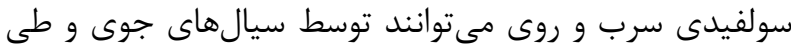

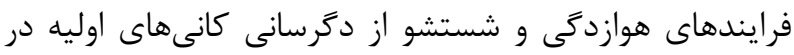
$(\mathrm{La} / \mathrm{Yb})_{\mathrm{N}}=$

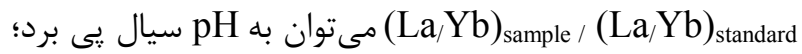

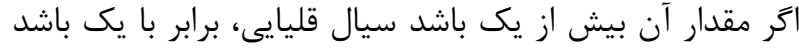

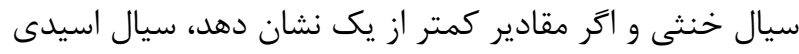

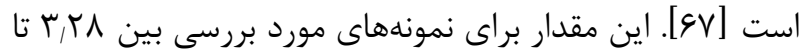

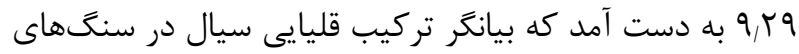
آهكى و دولوميتى ميزبان است. يكى از مسائل مههم در بررسى دولى دولوميتهان، بررسى خاستخاه

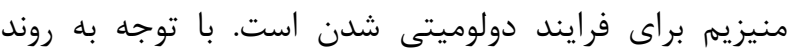

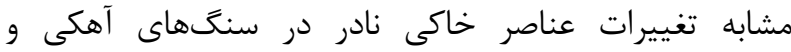

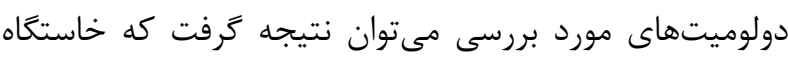

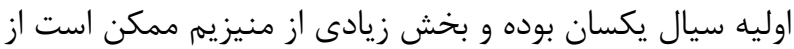

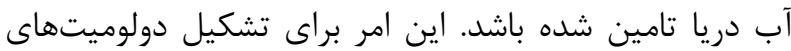

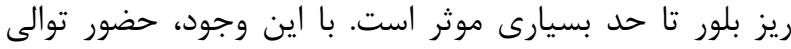

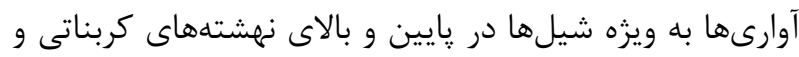

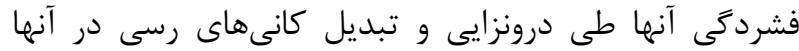

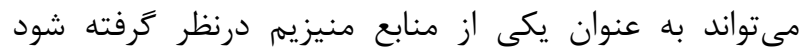

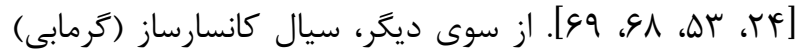

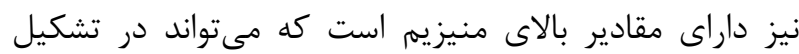

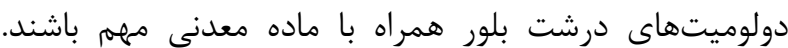

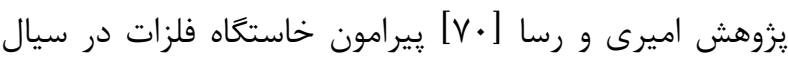

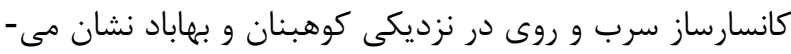

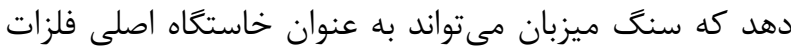

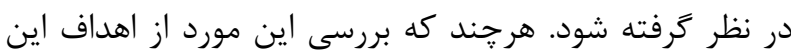

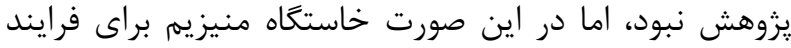

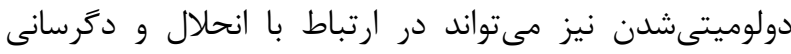

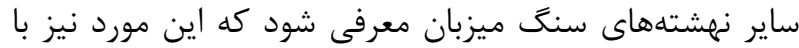

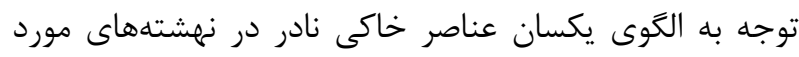

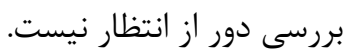

يا قرمز هستند كه نشانكر شرايط احيايى تشكيل آنها و

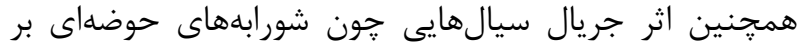

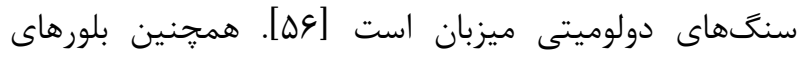
درشت دولوميت زين اسبى به صورت موضعى و اغلب يِيرامون

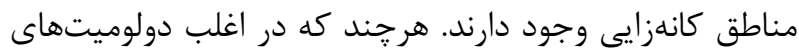

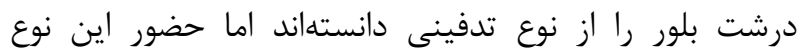

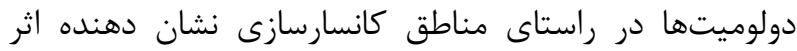

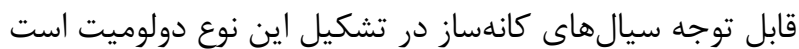
[ه9-DV]

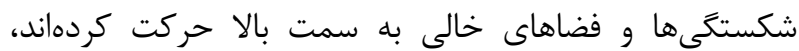
افزون بر تشكيل كانههاى مختلف و اوليه سرب و روى (از قبيل

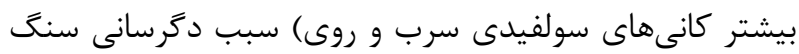

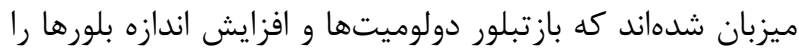

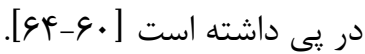
بررسى تهاى زمينشيميايى در نمونهاى سنگ ميزبان نشان

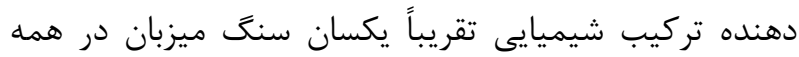

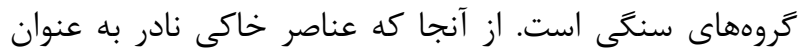

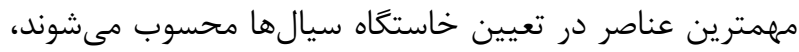

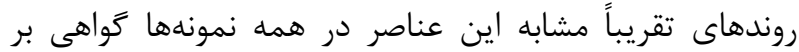
يكسان بودن خاستخاه سيال اوليه (زمان رسوبكذارى) است. با بان

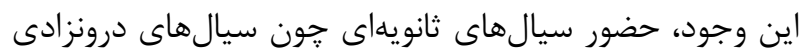
و سيالهاى كانهساز (كرمابى) بيشتر سبب تغيير اندازه و شكل

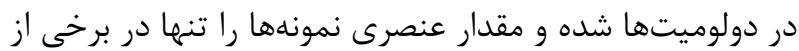
عناصر اصلى و فرعى تغيير داده است. دادههاى تجزيه عنصر

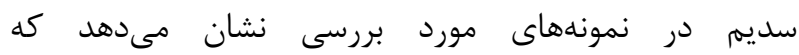
دولوميتهاى منطقه در معرض سيالى با شورى كمم تا بسيار

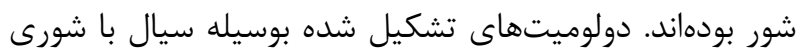

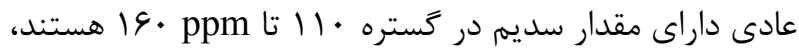

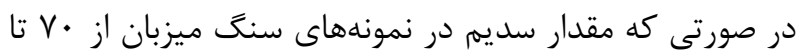

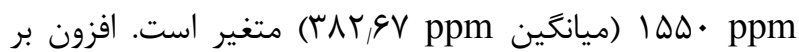
اين، محاسبه مقدار Sr/Ba نيز اين امر را تاييد كرده و نشان

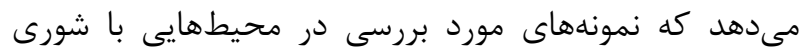

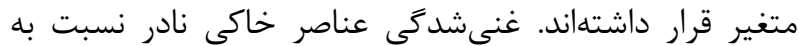

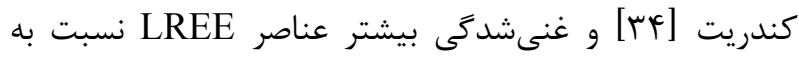

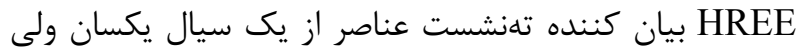

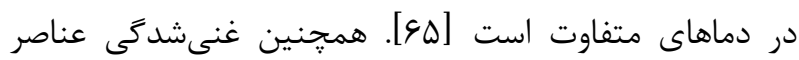
خاكى نادر در همه نمونهها نيز نشانكر اثر سيالهاى داى با خاستخاه

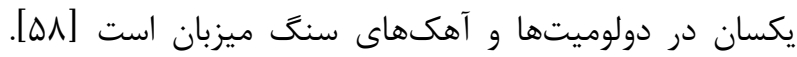

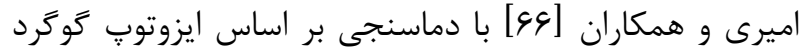

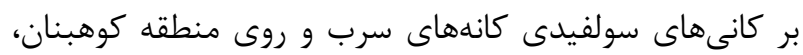


25th Symposium on Geosciences, Geological Survey of Iran, Tehran, (2006).

[9] Javanshir A., Mineralogy, geochemistry, facies analysis and genesis of $\mathrm{Zn}-\mathrm{Pb}(\mathrm{Mo})$ mineralization in Shotori Formation dolomites of the Ahmadabad deposit (NE-Bafq)," M.Sc. thesis, Tarbiat Modares University, Tehran, Iran (unpubl.), (2007).

[10] Rajabi A., Rastad E., Canet C., Metallogeny of Permian-Triassic carbonate-hosted $\mathrm{Zn}-\mathrm{Pb}$ and $F$ deposits of Iran: A review for future mineral exploration," Australian Journal of Earth Sciences, (2013), 60: 197-216.

[11] Luo K., Zhou J., Hang Z., Wang X., Wilde S., Zhou W., Tian L., New insights into the origin of early Cambrian carbonate-hosted $\mathrm{Pb}-\mathrm{Zn}$ deposits in South China: A case study of the Maliping PbZn deposit", Gondwana Research, (2019), 70: 88103.

[12] Aghanabati A., 'Geology of Iran. Ministry of Industry and Mines, Geological Survey and Mineral Exploration of Iran," (2010), 606 p. [In Persian]

[13] Mahdavi M.A., Soheili M., Mohajel M., Hajmola A., "Geological map for ravar, 1:250000", Geological survey of Iran, Tehran, (1996).

[14] Zamani F., Moussavi-Harami R., ZandMoghadam H., Mahboubi A., Lithofacies and petrofacies of red siliciclastic deposits in the Karavangah area, north of Kuhbanan: Dahoo or Sorkh-Shale Formation?", th Iranian Sedimentological Society Conference, Zanjan University, (2018), 1118p.

[15] Eskandari Nejad R., Zand-Moghadam H., Khorasani pour M., Mineralogy and geochemistry of sulfide zone of Tarz Pb-Zn mine, North of Kerman province: A case study of carbonatehosted sedimentary ore deposits," Journal of Srtatigraphy and Sedimentology Researches University of Isfahan, (2019), 1-22. [In Persian].

[16] Maghfouri S., Hosseinzadeh M., Rajabi A., Choulet A., "A review of major non-sulfide zinc deposite in Iran", Geoscience Frontiers, (2018), 9: 249-272.

[17] Dickson J., "A modified staining technique for carbonates in thin section," Nature, (1965), p. 205285.

[18] Dunham R.J., "Classification of carbonate rocks according to depositional texture," American

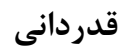

$$
\begin{aligned}
& \text { در اينجا لازم است تا از امكانات مادى و معنوى كروهوهاى }
\end{aligned}
$$

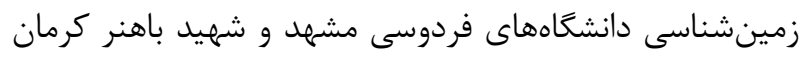

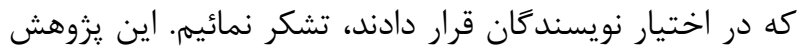

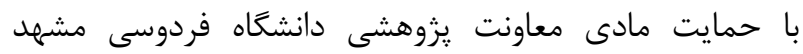

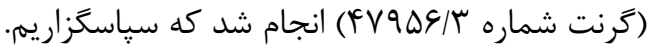

$$
\begin{aligned}
& \text { مراجع }
\end{aligned}
$$

[1] Amiri A., Ghorbani M., Akbarzadeh A., Shojaei Baghini S., New Trends on Non-Sulfur Zn and Pb Strataband Deposits in Kohbanan Area of Bahabad", 9th Iranian Geological Society Conference, Tehran, Iranian Geological Society, Tarbiat Moallem University, (2005),375-385. [In Persian]

[2] Eskandari Nejad R., "Geochemistry and Economic Evaluation of Lead and Zinc Deposits of Tarz Area, North of Kerman Province: Emphasis on Trace Elements", Shahid Bahonar University of Kerman, MSc Thesis, (2019),127p.

[3] Jalili V., Textural, Structural and Geochemical Characteristics of Lead and Zinc Minerals in PbZn Deposits of the Ravar-Kuhbanan Belt, Kerman Province", MSc Thesis, (2002), 199p.

[4] Rahju Guitari, M., "Geology and reproductive model of the Gojar Pb-Zn deposits in the LeadZinc belt of Ravar-Kuhbanan, Kerman province", M.Sc. Thesis, (2016), 140p.

[5] Ahmadi S., Study of geology, geochemistry, mineralogy and mineralization model of the Karvangah $\mathrm{Pb}-\mathrm{Zn}$ deposits, the lead-zinc belt of Ravar-Kohbanan-Bahabad, Shahid Bahonar University of Kerman," MSc thesis, (2019), 73p.

[6] Rajabi A., Rastad E., Canet C., Metallogeny of Cretaceous carbonate-hosted $\mathrm{Zn}-\mathrm{Pb}$ deposits of Iran: geotectonic setting and data integration for future mineral exploration," International Geology Review, (2012), 54, 1649-1672.

[7] Sabzehi M., Afruz A., "Analysis on Lead-zinc mineralizations in the Central Iran: Ravar, Kerman, Kuhbanan and Rafsanjan areas," Leadzinc prospecting plan, Iranian Ministry of Industries and Mines, (1990), internal report.

[8] Javanshir A., Rastad E., Mehry B., "Mo mineralization associated with $\mathrm{Zn}-\mathrm{Pb}$ in the Ahmadabad, Abheydar and Tajkuh deposits in Shotory formation, Bafq-Behabad district," The 
implications for REE mobility during carbonate diagenesis," Journal of Sedimentary Petrology, (1988), 58: 415-432.

[29] Webb G.E., Kamber B.S., Rare earth elements in Holocene reefal microbialites: a new shallow seawater proxy," Geochimica et Cosmochimica Acta, (2000), 64: 1557-1565.

[30] Kamber B., Webb G., The geochemistry of late Archaean microbial carbonate: Implications for ocean chemistry and continental erosion history", Geochimica Et Cosmochimica Acta, (2001), 65: 2509-2525.

[31] Nothdurft L. D., Webb G. E., Kamber B. S., Rare earth element geochemistry of Late Dovonian reefal carbonates, Canning Basin, Western Australia: confirmation of a seawater REE proxy in ancient limestone," Geochimica et Cosmochimica Acta, (2004), 68: 263-283.

[32] Barton E.D., Bau M., Alexander B., "Preservation of primary REE patterns without Ce anomaly during dolomitization of MidPaleoprotrozoic limestone and the potential reestablishment of marine anoxia immediately after the Great Oxidation Event", South African Journal of Geology, (2006), 109: 81-86.

[33] Racki G., Konigshof P., Belka Z., Dopieralska J., Pisarzowska A., Diverse depositional and geochemical signatures of the FrasnianFamennian global event in western Thailand reveal Palaeotethyan vs. Western Australian geotectonic affinities," Journal of Asian Earth Sciences, (2019).

[34] Taylor S. R., McLennan S. M., The Continental Crust: Its Composition and Evolution", Blackwell Scientific publication, Oxford, (1985).

[35] Amiri A., Study of the geological, geochemical and genesis charactristics of carbonate-hosted $\mathrm{Zn}-\mathrm{Pb}$ deposites in the RavarBafgh area," Islamic Azad University, Science and Research Unit, (2007), 320p.

[36] Dumas S., R.W.C. Arnott, J.B. Southard, Experiments on oscillatory-flow and combinedflow bed forms: implications for interpreting parts of the shallow-marine sedimentary record: Journal of Sedimentary Researches", (2005), 75: 501-513.
Assiciation of Petroleum Geologists, (1962), 1: 108-121.

[19] Sibley D. F., Gregg J. M., "Classification of dolomite rock textures," Journal of Sedimentary Research, (1987), 6: 57.

[20] Gillhaus A., Richter D., Meijer J., Neuser R., Stephan A., "Quantitative high resolution cathodoluminescence spectroscopy of diagenetic and hydrothermal dolomites", Sedimentary geology, (2001), 140: 191-199.

[21] Wei A., Xuo C., Xiang K., Li J., Liao C., Akhter Q., The ore-forming process of the Maoping $\mathrm{Pb}-\mathrm{Zn}$ deposit, northeastern Yunnan, China: constraints from cathodoluminescence (CL) petrography of hydrothermal dolomite," Ore Geology Reviews, (2015), 70: 562-577.

[22] Ciurana D., Corbella M., Cardellach E., Vindel E., Gras D., Griera A., Petrography and geochemistry of fault-controlled hydrothermal dolomites in the Riopar area (Prebetic Zone, SE Spain)," Marine and Petroleum Geology, (2016), 71: 310-328.

[23] Leach D. L., Bradley D. C., Hutson D., Pisarevsky S. A., Taylor R. D., Gardoll S. J., Sediment-Hosted Lead-Zinc Deposits in Earth History," Economic Geology, (2010), 105: 593625.

[24] Li Q., Jiang Z., Hu W., You X., Hao G., Zhang J., Wang X., 'Origin of dolomites in the Lower Cambrian Xiaoerbulak Formation in the Tarim Basin, $N W$ China: Implications for porosity development", Journal of Asian Earth Sciences, (2015), 115: 557-570.

[25] Liu Y. J., Elementary Geochemistry, Sience Press, Beijing," (1984), P. 53 [in Chinese].

[26] Gao X., Wang P., Li D., Peng Q., Wang C., $\mathrm{Ma}$ H., Petrologic characteristics and genesis of dolostone from the Campanian of the SK-I Well Core in the Songliao Basin, China", Geoscience Frontiers, (2012), 1-12.

[27] Mason B., Moore C., 'Principles of Geochemistry," Willey, (1982), 344p.

[28] Banner J.L, Hanson G.N., Meyers W.J., Rare earth element and $\mathrm{Nd}$ isotopic variations in regionally extensive dolomites from the Burlington-Keokuk Formation (Mississippian): 
[47] Wernette P., Weymer B., Trimble S., Hammond B., The Critical Zone of Coastal Barrier Systems," Development in Earth Surface Processes, (2015) 19: 497-522.

[48] Hou Y., Azmy K., Berra F., Jadoul F., Blamey N., Gleeson S., Brand U., 'Origin of Breno and Esino dolomites in the western southern Alps", implications. Marine and Petroleum Geology, (2016), 69: 38-52.

[49] Bayetgol A., Moussavi-Harami R., Mahboubi A., Depositional environments and sequence stratigraphy of siliciclastic-carbonate deposits of the Shirgasht Formation, local tectonic evidence and global sea level changes in the sedimentary process in the Kalmard Block, Central Iran," Stratigraphy and Sedimentology Research, (2015), 37-68. [In Persian].

[50] Hampson G.J., Storms J.E.A., "Geomorphological and sequence stratigraphic variability in wave-dominated, shoreface-shelf parasequences", Sedimentology, (2003), 50 :667701.

[51] Hampson G.J., Procter E.J., Kelly C., "Controls on isolated shallow-marine sandstone deposition and shelf construction: late Cretaceous Western Interior Seaway," northern Utah and Colorado. In: G.J. Hampson, R.J. Steel, P.M. Burgess and R.W. Dalrymple, (Eds.), "Recent Advances in Models of Siliciclastic ShallowMarine Stratigraphy", Society of Sedimentary Geology (SEPM), Special Publications., (2008), $90: 355-389$.

[52] Sternbach C.A., Friedman G.M., "Ferroan carbonates formed at depth require porosity well log correction: Hunton Group", Deep Anadarko Basin (Upper Ordovician to Lower Devonian) of Oklahoma and Texas. Transactions of Southwest Section. American Association of Petroleum Geologists Bulletin, (1984), 167-173.

[53] Adabi M., Multistage dolomitization of upper Jurassic Mozduran formation, Kopet-Dagh Basin, n.e. Iran", Carbonate and Evaporites, (2009), 24: 16-32.

[54] Sternbach C.A., Friedman G. M., Ferroan carbonates formed at depth require porosity well log correction: Hunton Group, deep Anadarko Basin (Upper Ordovician to lower Devonian) of Oklahoma and Texas: Transaction of Southwest
[37] Flugel E., Microfacies of Carbonate Rocks, Analysis, Interpretation and Application," Springer-Verlag, Berlin, (2010), 976p.

[38] Bassi D., Nebelsick J., 'Components, facies and ramps: redefining Upper Oligocene shallow water carbonates using coralline red algae and larger foraminifera (Venetian area, northest Italy), Palaeogeography, Palaeoclimatology", Palaeoecology, (2010), 295: 258-280.

[39] Shahraki J., Javdan M., Pahlavan Hashemi M., Jami M., Mastooh M., Kalvandi M., Facies Analysis, Depositional Environment of the Lower Permian Deposits of Chili Formation in Kalmard Block, Estern Central Iran, (Darin Section)," Open Journal of Geology, (2015), 5: 539-551.

[40] Gao Sh., 'Geomorphology and Sedimentology of Tidal Flats ", Coastal Wetlands, (2019), 359-381. [41] Schutte C., Ahmercamp S., Wu C., Seidel M., Dirk de Beer, Cook P., Joye S., Biogeochemical Dynamics of Coastal Tidal Flats", Coastal Wetlands, (2019), 407-440.

[42] Lasemi Y., Jahani D., Amin-Rasouli H., Lasemi Z., "Ancient carbonate tidalites", Springer, (2012), 567-607.

[43] Zand-Moghadam H., Moussavi-Harami R., Mahboubi A., Bavi H., "Comparison of Tidaites in Siliciclastic, Carbonate, and Mixed SiliciclasticCarbonate Systems: Example from Cambrian and Devonian Deposits of East-Central Iran", International Scholary Research Network Geology, (2013), 21.

[44] Birchard M.C., Rutka M.A., Brunton F.R., "Lithofacies and geochemistry of the lucas formation in the subsurface of Southwestern Ontario: a high purity limestone and Potential high purity dolostone resource", Ontario Geological Survey Open File report, (2004), 6137: $57 \mathrm{p}$.

[45] Zhao H., Jones B., "Genesis of fabricdestructivedolostones: A case study of the Brac Formation (Oligocene)," Cayman Brac, British West Indies. Sedimentary Geology, (2012), 36-54.

[46] Meister P., Mackenzie J., Bernasconi S., Brack P., Dolomite formation in the shallow seas of the Alpine Triassic ", Sedimentology, (2013), 60: 270-291. 
[63] Dewit J., Huysmans M., Muchez Ph., Hunt D., Thurmond J., Verges J., Saura E., Fernandez N., Romaire I., Esestime P., Swennen R., Reservoir characteristics of fault-controlled hydrothermal dolomite bodies: Ramales platform case study", Geological Society, London, Special Publication, (2012), v.370.

[64] Zheng H., Ma Y., Chi G., Qing H., Liu B., Zhang X., Shen Y., Liu J., Wang, Y., Stratigraphic and Srtucural Control on Hydrothermal Dolomitization in the Middle Permian Carbonates, Southwestern Sichuan Basin (China)", Minerals, (2019), 9: 32.

[65] Azomani E., Azmy K., Blamey N., Brand U., Al-Aasm I., 'Origin of Lower Ordovician dolomites in eastern Laurentia: Controls on porosity and implications from geochemistry," Marine and Petroleum Geology, (2012), 1-16.

[66] Amiri A., Rasa I., Khakzad A., Thermometry and Formation Model of Carbonate-hosted $\mathrm{Zn}-\mathrm{Pb}$ Sulfide Deposits in the Raver-Bafgh area Based on Sulfur Stable Isotopes," Journal of Earth Sciences, (2009), 72: 3-10. [In Persian].

[67] Zanganeh V., 'Geochemistry and Mineralogy of Urmia-Ashnouyeh Dolomites", Urmia University MSc Thesis, (2017), 115p.

[68] Mountjoy J.A., Amthor J.E, "Has burial dolomitization come of age? Some answer from the Western Canada Sedimentary Basin", In: Purser, B., Tucker, M., Zenger, D. (Eds.), Dolomites a Volume in Honour of Dolomieu. Special Publications of the International Association of Sedimentologists, (1994), 21: 203-229.

[69] Qing H., Bosence W.J., Rose E., "Dolomitization by penesaline sea water in Early Jurassic peritidal platform carbonates," Gibraltar western Mediterranean, Sedimentology, (2001), 48: 153-163.

[70] Amiri A., Rasa I., Determination of the origin of carbonate-hosted $\mathrm{Zn}-\mathrm{Pb}$ deposits in KuhbananBahabad area: mineralogical, geochemical evidence and pattern of rare elements", Lahijan Quarterly Periodical of Earth and Resources, (2009), 2: 21-42 .[In Persian]. section", American Assiciation of Petroleum Geologists, (1984), p.167-17. [In Persian].

[55] Karimzadeh F., Adabi M., Description of Different Kinds of Dolomites in Shotori Formation (Kouhbanan area) based on Petrographic and Geochemical studies with a reference to the Role of Shales in the Sorkh Shale Formation as a Major Source of Mg," Journal of Earth Sciences, (2008), 69: 110-129. [In Persian].

[56] Mahdavi M., Shafei-Bafti B, Amini A., Rasouli M., Dolomites and breccias in the Kamarposht Fluorite Mine, Elika Formation, Central Alborz", Iranian Geological Survey, (2018) , 47-62. [In Persian].

[57] Davies G., Smith L., Structurally controlled hydrothermal dolomite reservoir facies: An overview: Reply," American Assiciation of Petroleum Geologists, (2007), 91: 1342-1344.

[58] Hong L., Teng M., Xiucheng T., Wei Z., Guang H., Di X., Bing L., Shujiao Sh., Chengpeng S., "Origin of structurally controlled hydrothermal dolomite in epigenetic karst system during shallow burial: An example from Middle Permian Maokou Formation, central Sichuan Basin, SW China," Petroleum Exploration and Development, (2016), 43: 1000-1012.

[59] Jazi M.A., Karimpour M.H., Malekzadeh Shafaroudi A., Nakhlak carbonate-hosted Pb-(Ag) deposit, Isfahan province, Iran: a geological, mineralogical, geochemical, fluid inclusion, and sulfur isotope study", Ore Geology Reviews, (2017), 80: 27-47. [In Persian].

[60] Davies G., Smith L., Structurally controlled hydrothermal dolomite reservoir facies: An overview," American Association of Petroleum Geologists, (2006), 90: 1641-1690.

[61] Chen D., Structure-controlled hydrothermal dolomitization and hydrothermal dolomite reservoirs," Oil and Gas Geology, (2008), 25: 614622.

[62] Horgue M., iriarte E., Schroder S., FernandezMendiola P., Caline B., Corneyllie H., Fremont J., Sudrie M., Zerti S., Structrally controlled hydrothermal dolomites in Albian carbonates of the Ason valley, Besque Cantabrian Basin, Northern Spain," Marine and Petroleume Geology, (2010), 27: 1069-1092. 